\title{
Anionic Bismuth-Oxido Carboxylate Clusters with Transition Metal Countercations
}

\author{
Ismael I. Loera Fernandez, Samantha L. Donaldson, Desmond E. Schipper, Sohaila Andleeb, \\ Kenton H. Whitmire*
}

Rice University, Chemistry Department. 610o Main St. MS-6o. Houston, TX 77005

KEYWORDS Bismuth, Oxido Clusters, Crystallography

\begin{abstract}
Six new anionic bismuth-oxido clusters containing trifluoroacetate ligands were prepared. These include two new $\mathrm{Bi}_{6} \mathrm{O}_{8}$ clusters: $\left[\mathrm{M}(\mathrm{NCMe})_{2}\left(\mathrm{H}_{2} \mathrm{O}\right)_{4}\right]_{3}\left[\mathrm{Bi}_{6}\left(\mu_{3}-\mathrm{O}\right)_{4}\left(\mu_{3}-\mathrm{OH}\right)_{4}\left(\mathrm{CF}_{3} \mathrm{CO}_{2}\right)_{12}\right]$ with an octahedral $\mathrm{Bi}_{6} \mathrm{O}_{4}(\mathrm{OH})_{4}$ core $(\mathrm{M}=\mathrm{Ni}$, 1a; $\mathrm{Co}, \mathbf{1 b})$ and four $\mathrm{Bi}_{4} \mathrm{O}_{2}$ clusters: $\left\{\left[\mathrm{Co}(\mathrm{NCMe})_{6}\right]\left[\mathrm{Bi}_{4}\left(\mu_{3}-\mathrm{O}\right)_{2}\left(\mathrm{CF}_{3} \mathrm{CO}_{2}\right)_{10}\right]\right\}_{\mathrm{n}} \quad(\mathbf{2 a})$, $\quad\left\{\mathrm{Co}\left\{\mathrm{HC}(\mathrm{MeCO})_{2}(\mathrm{MeCNH})\right\}_{2}\right]\left[\mathrm{Bi}_{4}\left(\mu_{3}-\right.\right.$ $\left.\left.\mathrm{O})_{2}\left(\mathrm{CF}_{3} \mathrm{CO}_{2}\right)_{10}\right] \cdot \quad 2\left[\mathrm{CF}_{3} \mathrm{CO}_{2}\right] \cdot 2\left[\mathrm{CF}_{3} \mathrm{CO}_{2} \mathrm{H}\right] \cdot 2\left[\mathrm{H}_{2} \mathrm{O}\right]\right\}_{\mathrm{n}} \quad(\mathbf{2 b}), \quad\left\{\left[\mathrm{Cu}(\mathrm{NCMe})_{4}\right]_{2}\left[\mathrm{Bi}_{4}\left(\mu_{3}-\mathrm{O}\right)_{2}\left(\mathrm{CF}_{3} \mathrm{CO}_{2}\right)_{10}\right] \cdot 2\left[\mathrm{CF}_{3} \mathrm{CO}_{2} \mathrm{H}\right]\right\}_{\mathrm{n}} \quad(\mathbf{2 c})$, and $\left\{\left[\mathrm{Me}_{4} \mathrm{~N}\right]_{2}\left[\mathrm{Bi}_{4}\left(\mu_{3}-\mathrm{O}\right)_{2}\left(\mathrm{CF}_{3} \mathrm{CO}_{2}\right)_{10}\right] \cdot 2\left[\mathrm{CF}_{3} \mathrm{CO}_{2} \mathrm{H}\right]\right\}_{\mathrm{n}}(\mathbf{2 d})$. These are among the first bismuth-oxido anionic clusters synthesized and the first to have transition metal countercations. The $\mathrm{Bi}_{6} \mathrm{O}_{8}$ anion in $\mathbf{1 a}$ and $\mathbf{1 b}$ is a high-symmetry octahedron. Additionally, two of the new $\mathrm{Bi}_{4} \mathrm{O}_{2}$ clusters are arranged in ${ }_{1} \mathrm{D}$ polymeric structures via bridging carboxylate ligands. The cation in compound $\mathbf{2 c}$ had not been previously characterized and was also observed in the synthesis of $\left[\mathrm{Co}\left\{\mathrm{HC}(\mathrm{MeCO})_{2}(\mathrm{MeCNH})\right\}_{2}\right]\left[\mathrm{Bi}\left(\mathrm{NO}_{3}\right)_{6}\right](3)$. The new compounds were characterized using single crystal x-ray crystallography and elemental analysis.
\end{abstract}

Bismuth is a useful component of many drugs with potential for diverse chemical and biological applications. ${ }^{1-4}$ Its unique properties along with its nontoxicity has led bismuth to be utilized in alloys, non-toxic pigments, thermoelectric and ferroelectric materials, and in catalysts. ${ }^{5,6}$ Bismuth-oxido clusters have drawn attention from several groups, as they highlight bismuth's ability to form large, multinuclear oxido complexes. ${ }^{7-18}$ These clusters are readily synthesized via hydrolysis of the bismuth(III) compounds and can be used as precursors for bismuth-based solid state materials applications. $^{19-21}$

Bismuth compounds have long been known to undergo hydrolysis. The halides, such as $\mathrm{BiCl}_{3}$, readily form the subhalides $\mathrm{BiOX}$ upon treatment with water, although hydrated intermediates have been observed. ${ }^{22}$ The products of the hydrolysis of bismuth nitrate and perchlorate have been studied crystallographically and show the formation of discrete oxido cluster species. ${ }^{13,15,23-29}$ Complexes with salicylate $\left(\mathrm{H}_{2} \mathrm{sal}=\mathrm{HO}-2-\mathrm{C}_{6} \mathrm{H}_{4} \mathrm{CO}_{2} \mathrm{H}\right)$ were particularly of interest owing to the known biological activity of bismuth subsalicylate. Among the nuclearities observed for that ligand alone are $\left[\mathrm{Bi}_{4}\left(\mu_{3}-\mathrm{O}\right)_{2}(\mathrm{Hsal})_{8}\right] \cdot 2 \mathrm{Solv}\left(\mathrm{Solv}=\mathrm{MeCN} \text { or } \mathrm{MeNO}_{2}\right)^{22}$ $\left[\mathrm{Bi}_{9} \mathrm{O}_{7}(\mathrm{Hsal})_{13}\left(\mathrm{Me}_{2} \mathrm{CO}\right)_{1.5}\right] \cdot\left(\mathrm{Me}_{2} \mathrm{CO}\right)_{1.5}{ }^{3},\left[\mathrm{Bi}_{22} \mathrm{O}_{24}(\mathrm{Hsal})_{14}\right],{ }^{30,31}$ $\left[\mathrm{Bi}_{38} \mathrm{O}_{45}(\mathrm{Hsal})_{22}(\mathrm{OH})_{2}(\mathrm{DMSO})_{16.5}\right] \cdot \mathrm{DMSO}-\cdot \mathrm{H}_{2} \mathrm{O},{ }^{30,31}$ $\left[\mathrm{Bi}_{38} \mathrm{O}_{44}(\mathrm{Hsal})_{26}\left(\mathrm{Me}_{2} \mathrm{CO}\right)_{16}\left(\mathrm{H}_{2} \mathrm{O}\right)_{2}\right] \cdot\left(\mathrm{Me}_{2} \mathrm{CO}\right)_{4}{ }^{3,16,32} \quad$ Oxidoclusters supported by alkoxides, other carboxylates and hex-

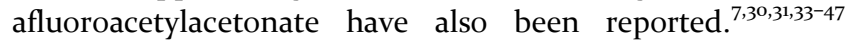
They contain a core composed of $\mathrm{Bi}$ (III) and oxygen atoms that has an overall positive charge. These cores are then surrounded by negatively charged carboxylate ligands to form an overall neutral compound. A common structural motif in these systems is the observation of the octahedral $\mathrm{Bi}_{6} \mathrm{O}_{8}{ }^{2+}$ core in which oxide ions (or hydroxide) adopting $\mu_{3}$ bridging configurations on each of the octahedral faces. The same octahedral component is found as a subunit in the larger bismuth alkoxide and carboxylate structures. For the latter, a variety of nuclearities have been observed.

Negatively charged bismuth-oxido carboxylate clusters on the other hand are rare. The $\left[\left\{\mathrm{Bi}_{38} \mathrm{O}_{45}\left(\mathrm{C}_{4} \mathrm{H}_{7} \mathrm{SO}_{3}\right)_{8}\left(\mathrm{NO}_{3}\right)_{14}(\mathrm{dmso})_{19.5}\left(\mathrm{H}_{2} \mathrm{O}\right)_{2}\right\}\right]^{2+}$ cation is found paired with the anionic cluster $\left[\left\{\mathrm{Bi}_{38} \mathrm{O}_{45}\left(\mathrm{C}_{4} \mathrm{H}_{7} \mathrm{SO}_{3}\right)_{10}\left(\mathrm{NO}_{3}\right)_{16}(\mathrm{dmso})_{16}\left(\mathrm{H}_{2} \mathrm{O}\right)_{2}\right\}\right]^{2-} .^{48}$ The reaction of $\mathrm{Bi}\left(\mathrm{O}_{3} \mathrm{SCF}_{3}\right)$ with organodichalcogenones has produced [Bi(1,1'-methylenebis(3-methyl-1,3-dihydro-2H-imidazole-2thione $\left.)_{6}\right]^{3+}$ paired with $\left[\mathrm{Bi}_{6}(\mathrm{OH})_{8}\left(\mathrm{O}_{3} \mathrm{SCF}_{3}\right)_{12}\right]^{3-} .49$

The products of the reaction of bismuth trifluoroacetate hydrolysis in aqueous solutions and thermolysis in arene solvents have been reported by Kugel. ${ }^{5}$ He observed the formation of the unit $\mathrm{Bi}_{3} \mathrm{O}\left(\mathrm{O}_{2} \mathrm{CCF}_{3}\right)_{7}$ ligated by arenes both in monomeric and dimeric forms, ${ }^{50}$ but he also characterized $\mathrm{Bi}_{6} \mathrm{O}_{8}{ }^{\mathrm{n}+} \quad$ species in $\left[\mathrm{Bi}_{6} \mathrm{O}_{5}(\mathrm{OH})_{3}\left(\mathrm{H}_{2} \mathrm{O}\right)_{2}\left(\mathrm{O}_{2} \mathrm{CCF}_{3}\right)_{2}\right]_{2}\left[\mathrm{Bi}\left(\mathrm{O}_{2} \mathrm{CCF}_{3}\right)_{5}\right]_{3} \cdot 4 \mathrm{H}_{2} \mathrm{O}$ and $\left[\mathrm{Bi}_{6} \mathrm{O}_{4}(\mathrm{OH})_{4}\right]\left[\mathrm{Bi}_{10} \mathrm{O}_{8}\left(\mathrm{O}_{2} \mathrm{CCF}_{3}\right)_{20}\right] .^{50}$ In the latter compound, the $\left[\mathrm{Bi}_{10} \mathrm{O}_{8}\left(\mathrm{O}_{2} \mathrm{CCF}_{3}\right)_{2 \mathrm{O}}\right]^{6-}$ ion is described as a $\mathrm{Bi}_{6} \mathrm{O}_{8}{ }^{2+}$ cluster coordinated to four $\left[\mathrm{Bi}\left(\mathrm{O}_{2} \mathrm{CCF}_{3}\right)_{5}\right]^{2-}$ fragments.

In continuation of our previous studies on bismuth carboxylates formed by reaction of $\mathrm{BiPh}_{3}$ and carboxylic acids, ${ }^{32,51-55}$ we have examined reactions with trifluoroacetic acid. Performing reactions similar to those previously reported but in the presence of a metal cation source, the synthesis and structure of six new anionic bismuth-oxido clusters with 
trifluoroacetate ligands are described. Our initial motivation was to create heterobimetallic complexes in situ by formation of $\mathrm{Bi}\left(\mathrm{O}_{2} \mathrm{CR}\right)_{3}$ in the presence of $\mathrm{M}(\mathrm{acac})_{3}$ complexes based on our prior observations of coordination of $\mathrm{M}(\mathrm{acac})_{3}$ to the bismuth carboxylates. ${ }^{56}$ We discovered, however, that under these conditions the $\mathrm{M}(\mathrm{acac})_{3}$ are not stable and provide a templating metal counterion that systematically promotes the formation of anionic bismuth oxido carboxylates. Use of other non-acac metal complexes as well as organic

Table 1. Summary of synthesis of anionic bismuth-oxido clusters using transition metal countercations. Triphenylbismuth and trifluoroacetic acid were also reactants for all reactions.

\begin{tabular}{lllll}
\hline Compound & Solvent Used & Transition Metal Source & Cation Synthesized & Anion Synthesized \\
\hline 1a & MeCN & Ni(II) formate & {$\left[\mathrm{Ni}(\mathrm{NCMe})_{2}\left(\mathrm{H}_{2} \mathrm{O}\right)_{4}\right]^{2+}$} & {$\left[\mathrm{Bi}_{6} \mathrm{O}_{4}\left(\mathrm{OH}_{4}\left(\mathrm{CF}_{3} \mathrm{CO}_{2}\right)_{12}\right]^{6-}\right.$} \\
1b & MeCN & $\mathrm{Co}(\mathrm{II})$ acetate & {$\left[\mathrm{Co}(\mathrm{NCMe})_{2}\left(\mathrm{H}_{2} \mathrm{O}\right)_{4}\right]^{2+}$} & {$\left[\mathrm{Bi}_{6} \mathrm{O}_{4}\left(\mathrm{OH}_{4}\left(\mathrm{CF}_{3} \mathrm{CO}_{2}\right)_{12}\right]^{6-}\right.$} \\
$2 \mathrm{a}$ & $\mathrm{MeCN} /$ toluene & $\mathrm{Co}(\mathrm{III})$ acac & {$\left[\mathrm{Co}(\mathrm{NCMe})_{6}\right]^{2+}$} & {$\left[\mathrm{Bi}_{4} \mathrm{O}_{2}\left(\mathrm{CF}_{3} \mathrm{CO}_{2}\right)_{10}\right]^{2-}$} \\
$2 \mathrm{~b}$ & $\mathrm{MeCN}$ & $\mathrm{Co}(\mathrm{III})$ acac & {$\left[\mathrm{Co}\left\{\mathrm{HC}(\mathrm{MeCO})_{2}(\mathrm{MeCNH})_{2}\right]^{3+}\right.$} & {$\left[\mathrm{Bi}_{4} \mathrm{O}_{2}\left(\mathrm{CF}_{3} \mathrm{CO}_{2}\right)_{10}\right]^{2-}$} \\
$2 \mathrm{C}$ & $\mathrm{MeCN}$ & $\mathrm{Cu}(\mathrm{I})$ oxide & {$\left[\mathrm{Cu}(\mathrm{NCMe})_{4}\right]^{+}$} & {$\left[\mathrm{Bi}_{4} \mathrm{O}_{2}\left(\mathrm{CF}_{3} \mathrm{CO}_{2}\right)_{10}\right]^{2-}$}
\end{tabular}

\section{RESULTS AND DISCUSSION}

A number of years ago we developed the solvolysis of $\mathrm{BiPh}_{3}$ by acidic alcohols and carboxylic acids to produce cleanly $\mathrm{Bi}(\mathrm{OR})_{3}$ and $\mathrm{Bi}\left(\mathrm{O}_{2} \mathrm{CR}\right)_{3}$ derivatives. ${ }^{55,57}$ This provided a convenient facile and high yield route that avoided complications using traditional salt metathesis methods. The complexes so produced proved to be sensitive to hydrolysis and a variety of bismuth oxido clusters were obtained as a result. ${ }^{9,36,58,59}$ Andrews developed this methodology to produce $\mathrm{Bi}_{9}$ and $\mathrm{Bi}_{38}$ oxido salicylate clusters. ${ }^{3}$ More recently we have turned to examining trifluoroacetate as an oxidatively-stable ligand for preparation of bismuth oxido compounds. Earlier work on hydrolysis and decomposition of bismuth trifluoroacetate in aqueous and arene solvents has been reported in the thesis of B. Kugel. ${ }^{5^{\circ}}$ We had observed earlier that metal acac complexes can form complexes with $\mathrm{Bi}(\mathrm{Hsal})_{3}{ }^{56}$ and decided to explore synthesis of bismuth carboxylates in the presence of various metal acac complexes as a direct route to heterometallic compounds. Simple addition of the acac complexes did not occur in this case. Rather, acid promoted conversion of the metal acac species into other metal cations was observed with the unexpected consequence that the presence of these metal cations in solution gave rise to new anionic bismuth oxido clusters where the transition metal served as a simple counterion. Based on that observation, a variety of other metal complexes were used to explore the generality of the reaction. Organic cations may also be used. Depending on conditions either the octahedral $\left[\mathrm{Bi}_{6}\left(\mu_{3}-\mathrm{O}\right)_{4}\left(\mu_{3}-\right.\right.$ $\left.\mathrm{OH})_{4}(\mathrm{tfa})_{12}\right]^{6-}\left(\mathrm{tfa}^{-}=\mathrm{CF}_{3} \mathrm{CO}_{2}^{-}\right)$or essentially planar $\left[\mathrm{Bi}_{4}\left(\mu_{3}-\right.\right.$ $\left.\mathrm{O})_{2}(\mathrm{tfa})_{\mathrm{x}}\right]^{2-}(\mathrm{x}=9,10)$ species were obtained. Table 1 gives an overview of the different conditions used to synthesize these new bismuth-oxido clusters with transition metal cations.

Octahedral $\left[\mathrm{M}(\mathrm{NCMe})_{2}\left(\mathrm{H}_{2} \mathrm{O}\right)_{4}\right]_{3}\left[\mathrm{Bi}_{6} \mathrm{O}_{4}(\mathrm{OH})_{4}(t f a)_{12}\right](\mathrm{M}=\mathrm{Ni}$, Co)

The compounds $\mathbf{1 a}$ and $\mathbf{1 b}$ were synthesized by dissolving $\mathrm{BiPh}_{3}$ in acetonitrile $(\mathrm{MeCN})$ followed by addition of trifluoroacetic acid and either nickel(II) formate or cobalt(II) counterions has also proven effective for the production of these complexes. Herein we report the formation of two salts of $\left[\mathrm{Bi}_{6} \mathrm{O}_{4}(\mathrm{OH})_{4}\left(\mathrm{O}_{2} \mathrm{CCF}_{3}\right)_{12}\right]^{6-}$ and four complexes containing polymeric $\left\{\left[\mathrm{Bi}_{4} \mathrm{O}_{2}\left(\mathrm{O}_{2} \mathrm{CCF}_{3}\right)_{10}\right]^{2-}\right\}_{\mathrm{n}}$ anions.

acetate tetrahydrate. The complexes crystallized from solution upon standing, but the nickel reaction has proven more difficult to reproduce, unlike the cobalt reaction that always worked well. The new highly symmetrical anionic bismuth-oxido cluster anion $\left[\mathrm{Bi}_{6}\left(\mu_{3}-\mathrm{O}\right)_{4}\left(\mu_{3}-\mathrm{OH}\right)_{4}(\mathrm{tfa})_{12}\right]^{6-}$ crystallized as either the $\left[\mathrm{Ni}(\mathrm{NCMe})_{2}\left(\mathrm{H}_{2} \mathrm{O}\right)_{4}\right]^{2+}(\mathbf{1 a})$ or $\left[\mathrm{Co}(\mathrm{NCMe})_{2}\left(\mathrm{H}_{2} \mathrm{O}\right)_{4}\right]^{2+}(\mathbf{l b})$ salts under these conditions. The cation $\left[\mathrm{Ni}(\mathrm{NCMe})_{2}\left(\mathrm{H}_{2} \mathrm{O}\right)_{4}\right]^{2+}$ has been reported once previously, as known of both the cations and anions (Table 2, Figure 1). There are three $\mathrm{ML}_{\mathrm{n}}{ }^{2+}$ cations per oxido cluster, requiring that the overall charge on the cluster be +6 . This is only achieved is there are equal number of $\mathrm{O}^{2-}$ and $\mathrm{OH}^{-}$ ligands giving the formula of the anion to be $\left[\mathrm{Bi}_{6} \mathrm{O}_{4}(\mathrm{OH})_{4}(\mathrm{tfa})_{12}\right]^{6-}$. The $\mathrm{H}_{2} \mathrm{O}$ and $\mathrm{MeCN}$ ligands of the cation are disordered over two positions. The fundamental solvolysis process can be written as shown in Equation 1.

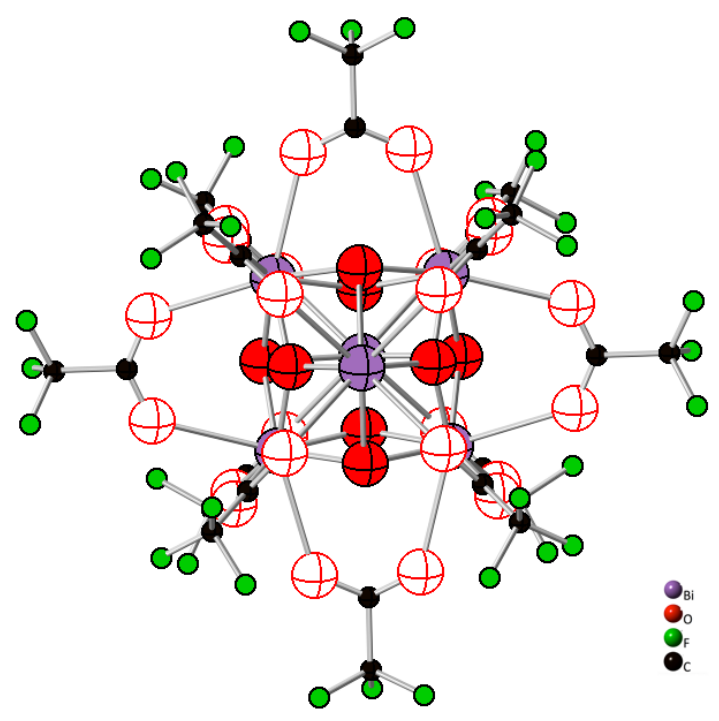

Figure 1. Molecular structure for the anionic portion of 1a, $\left[\mathrm{Ni}(\mathrm{NCMe})_{2}\left(\mathrm{H}_{2} \mathrm{O}\right)_{4}\right]_{3}\left[\mathrm{Bi}_{6}\left(\mu_{3}-\mathrm{O}\right)_{4}\left(\mu_{3}-\mathrm{OH}\right)_{4}(\mathrm{tfa})_{12}\right]$. The structure of $\mathbf{~} \mathbf{b}$ is identical. Only one set of the disordered fluo- 
rine atom positions is shown and thier displacement ellipsoids have been omitted for clarity.

Table 2. Selected Crystallographic data collection and refinement parameters for $\mathbf{1 a}$ and $\mathbf{1 b}$.

\begin{tabular}{lll} 
Compound & 1a & $1 \mathrm{~b}$ \\
\hline $\begin{array}{l}\text { Formula } \\
\begin{array}{l}\text { Crystal Sys- } \\
\text { tem }\end{array}\end{array}$ & $\mathrm{Bi}_{6} \mathrm{Ni}_{3} \mathrm{C}_{36} \mathrm{H}_{46} \mathrm{O}_{44} \mathrm{~N}_{6} \mathrm{~F}_{36}$ & $\mathrm{Bi}_{6} \mathrm{Co}_{3} \mathrm{C}_{36} \mathrm{H}_{46} \mathrm{O}_{44} \mathrm{~N}_{6} \mathrm{~F}_{36}$ \\
Space Group & $\mathrm{Pm} \overline{3}$ & cubic \\
\end{tabular}

$\begin{array}{lll}a, \AA & 14.906(2) & 14.8825(3) \\ \mathrm{V} & 3312.1(15) & 3296.3(2) \\ \mathrm{Z} & 1 & 1 \\ \mathrm{R} ; \mathrm{wR}_{2} & 0.0422 ; 0.1307 & 0.0480 ; 0.1393 \\ \text { GOF } & 1.139 & 1.109\end{array}$

$6 \mathrm{BiPh}_{3}+6 \mathrm{CF}_{3} \mathrm{CO}_{2} \mathrm{H}+6 \mathrm{CF}_{3} \mathrm{CO}_{2}^{-}+8 \mathrm{H}_{2} \mathrm{O} \rightarrow$

$\left[\mathrm{Bi}_{6} \mathrm{O}_{4}(\mathrm{OH})_{4}\left(\mathrm{CF}_{3} \mathrm{CO}_{2}\right)_{12}\right]^{6-}+18 \mathrm{Ph}-\mathrm{H}$

(1) 
The $\mathrm{Bi}_{6} \mathrm{O}_{4}(\mathrm{OH})_{4}{ }^{6+}$ core is highly symmetric, with the four oxide and four hydroxide ligands being refined in a statistically-disordered model over the eight faces of the $\mathrm{Bi}_{6}$ octahedron as required by the crystallographic Oh site symmetry. This is essentially a superposition of two orientations of the molecules with rigorous $\mathrm{Td}$ symmetry as shown in $\mathbf{1}$, consistent with prior reports of similar $\mathrm{Bi}_{6}$ oxido cations (Table 3). In this disorder model, each face of the $\mathrm{Bi}_{6}$ octahedron is bridged by a 1:1ratio of $\mathrm{O}$ and $\mathrm{OH}$ that were each refined each at half occupancy resulting from the imposition of a crystallographic inversion center in the centroid of the $\mathrm{Bi}_{6}$ octahedron of $\mathbf{1}$. The trifluoroacetate ligands symmetrically bridge each $\mathrm{Bi}$ - $\mathrm{Bi}$ vector, making the bismuth atoms overall 8-coordinate. The octahedral $\mathrm{Bi}_{6} \mathrm{O}_{8-}$ ${ }_{\mathrm{x}}(\mathrm{OH})_{\mathrm{x}}{ }^{\mathrm{n}+}$ core is well-known. Previously reported examples are given in Table 3. The cationic species have a variety of interactions with the corresponding anions that stabilize the central highly symmetrical oxido cluster. The anionic species synthesized have slightly shorter $\mathrm{Bi}-\mathrm{O}$ bond lengths than most of the known neutral or cationic species.

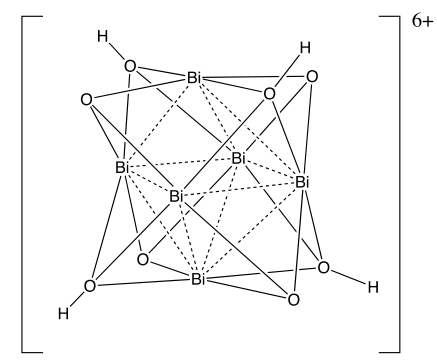

(1)

Table 3. Comparison of the $\mathrm{Bi}-\mathrm{O}$ and $\mathrm{Bi}-\mathrm{OH}$ bond distances in the known compounds containing a $\left[\mathrm{Bi}_{6} \mathrm{O}_{\mathrm{x}}(\mathrm{OH})_{\mathrm{y}}\right](+18-2 \mathrm{x}-\mathrm{y})$ core $(\mathrm{Tf}=$ $\mathrm{CF}_{3} \mathrm{SO}_{3}^{-}$)

\begin{tabular}{|c|c|c|c|}
\hline Compound & $\begin{array}{l}\mathrm{d}_{\mathrm{Bi}-\mathrm{O}} \\
\text { À ave. }\end{array}$ & $\begin{array}{l}\mathrm{d}_{\mathrm{Bi}-} \\
\mathrm{OH}, \AA \\
\text { ave. }\end{array}$ & Ref \\
\hline 1a & 2.159 & 2.382 & \\
\hline $1 b$ & 2.148 & 2.373 & \\
\hline $\left.\mathrm{Bi}_{6} \mathrm{O}_{4}(\mathrm{OH})_{4}\left(\mathrm{H}_{2} \mathrm{O}\right)\left(\mathrm{NO}_{3}\right)\right]\left[\mathrm{NO}_{3}\right]_{5}$ & 2.169 & 2.423 & 13 \\
\hline$\left[\mathrm{Bi}_{6} \mathrm{O}_{4}(\mathrm{OH})_{4}\right]\left(\mathrm{NO}_{3}\right)_{6 \cdot 4} \mathrm{H}_{2} \mathrm{O}$ & 2.162 & 2.399 & 24 \\
\hline$\left[\mathrm{Bi}_{6} \mathrm{O}_{5}(\mathrm{OH})_{3}\right]\left(\mathrm{NO}_{3}\right)_{5} \cdot 3 \mathrm{H}_{2} \mathrm{O}$ & 2.213 & 2.374 & 25 \\
\hline $\mathrm{Bi}_{6} \mathrm{O}_{4}(\mathrm{OH})_{4}\left(\mathrm{ClO}_{4}\right)_{6 \cdot 7} \mathrm{H}_{2} \mathrm{O}$ & 2.154 & 2.402 & 27 \\
\hline $\mathrm{Bi}_{6} \mathrm{O}_{4}(\mathrm{OH})_{4}\left(\mathrm{NO}_{3}\right)_{6} \mathrm{H}_{2} \mathrm{O}$ & 2.163 & 2.423 & 28 \\
\hline$\left[\mathrm{Bi}_{6} \mathrm{O}_{4}(\mathrm{OH})_{4}(\mathrm{OTf})_{6}(\mathrm{NCMe})_{6}\right]{ }_{2} \mathrm{MeCN}$ & 2.162 & 2.397 & 16 \\
\hline $\begin{array}{l}{\left[\mathrm{NH}_{4}\right]_{6}\left[\mathrm{Bi}_{6} \mathrm{O}_{4} \mathrm{OH}(\mathrm{cit})_{3}\left(\mathrm{H}_{2} \mathrm{O}\right)_{3}\right]} \\
{[\text { Hcit }] .2 \mathrm{H}_{2} \mathrm{O}+}\end{array}$ & 2.212 & 2.495 & 60 \\
\hline$\left(\mathrm{NH}_{4}\right)_{12}\left[\mathrm{Bi}_{12} \mathrm{O}_{8}(\mathrm{cit})_{8}\right]\left(\mathrm{H}_{2} \mathrm{O}\right)_{10}$ * & 2.181 & 2.470 & 61 \\
\hline $\begin{array}{l}{\left[\mathrm{Bi}_{12}\left(\mu_{3}-\mathrm{OH}\right)_{4}\left(\mu_{2}-\mathrm{OH}\right)_{2}\left(\mu_{3}-\mathrm{O}\right)_{8}\left(\mu_{4^{-}}\right.\right.} \\
\left.\mathrm{O})_{2}\left(\mathrm{NO}_{3}\right)_{6}\right]\left(\mathrm{NO}_{3}\right)_{4} \cdot 6 \mathrm{H}_{2} \mathrm{O}^{*}\end{array}$ & 2.191 & 2.405 & "1 \\
\hline$\left[\mathrm{Bi}_{10} \mathrm{O}_{8}\left(\mathrm{O}_{2} \mathrm{CCF}_{3}\right)_{20}\right]\left[\mathrm{Bi}_{6} \mathrm{O}_{4}(\mathrm{OH})_{4}\right]$ & 2.165 & 2.343 & 50 \\
\hline$\left[\mathrm{Bi}_{6} \mathrm{O}_{4}(\mathrm{OH})_{4}\left(\mathrm{NO}_{3}\right)_{5}\left(\mathrm{H}_{2} \mathrm{O}\right)\right]\left(\mathrm{NO}_{3}\right)$ & 2.160 & 2.409 & 62 \\
\hline$\left[\mathrm{Bi}_{6} \mathrm{O}_{4}(\mathrm{OH})_{4}\left(\mathrm{NO}_{3}\right)_{6}\left(\mathrm{H}_{2} \mathrm{O}\right)_{2}\right] \cdot \mathrm{H}_{2} \mathrm{O}$ & 2.158 & 2.396 & 62 \\
\hline $\mathrm{Bi}_{6} \mathrm{O}_{4}(\mathrm{OH})_{4}\left(\mathrm{NO}_{3}\right)_{12}\left(\mathrm{HOC}_{2} \mathrm{H}_{4} \mathrm{NH}_{3}\right)_{6}$ & 2.224 & 2.299 & $6_{3}$ \\
\hline$\left[\mathrm{Bi}(\mathrm{mbit})_{3}\right]\left[\mathrm{Bi}_{6} \mathrm{O}_{4}(\mathrm{OH})_{4}(\mathrm{Tf})_{12}\right](\mathrm{Tf})$ & 2.204 & 2.314 & 49 \\
\hline$\left[\mathrm{Bi}_{6} \mathrm{O}_{4}(\mathrm{OH})_{4}\left(\mathrm{H}_{2} \mathrm{O}\right)_{6}\left(\mathrm{NTf}_{2}\right)_{6}\right.$ & 2.165 & 2.404 & 64 \\
\hline
\end{tabular}

$\left[\mathrm{Bi}_{6} \mathrm{O}_{4}(\mathrm{OH})_{4}\left(\mathrm{H}_{2} \mathrm{O}\right)_{2}\right]\left[\left(\mathrm{CH}_{2}\right)_{2}\left(\mathrm{SO}_{3}\right)_{2}\right]_{3} \quad 2.164 \quad 2.407$

*compounds containing two connected octahedral $\mathrm{Bi}_{6}$ units $\dagger$ cit $=$ citrate

Anionic $\mathrm{Bi}_{4}\left(\mu_{3}-\mathrm{O}\right)_{2}$ Compounds

A new series of anionic compounds containing the $\mathrm{Bi}_{4}\left(\mu_{3}-\mathrm{O}\right)_{2}$ core with 10 trifluoracetate ligands and various cations were characterized and a summary of the crystallographic data collection and refinement parameters is provided in Table 4 . These syntheses were easily reproducible. The methodology was essentially the same as that leading to the octahedral Bi oxido compounds $\mathbf{1 a}$ and $\mathbf{1 b}$. The cations included $\quad\left[\mathrm{Co}(\mathrm{NCMe})_{6}\right]^{2+} \quad$ (2a), $\left[\mathrm{Co}\left\{\mathrm{HC}(\mathrm{MeCO})_{2}(\mathrm{MeCNH})\right\}_{2}\right]^{3^{+}}(\mathbf{2 b}),\left[\mathrm{Cu}(\mathrm{NCMe})_{4}\right]^{+} \quad(\mathbf{2 c})$, and $\mathrm{Me}_{4} \mathrm{~N}^{+}(\mathbf{2 d})$ cations for $\left\{\left[\mathrm{Bi}_{4}\left(\mu_{3}-\mathrm{O}\right)_{2}(\mathrm{tfa})_{1 \mathrm{o}}\right]^{2-}\right\}_{\mathrm{n}}$. While it was originally intended that the metal ions would be incorporated into the bismuth oxido cluster framework, the presence of the metal ions provides a means of conceptually adding $\left[\mathrm{ML}_{\mathrm{n}}\right]\left[\mathrm{O}_{2} \mathrm{CCF}_{3}\right]_{\mathrm{x}}$ to the neutral $\left[\mathrm{Bi}_{4}\left(\mu_{3}-\mathrm{O}\right)_{2}(\mathrm{tfa})_{8}\right]$, a compound which has not been previously reported but is known for several other carboxylates.

Table 4. Selected Crystallographic data collection and refinement parameters for compounds containing a $\mathrm{Bi}_{4}\left(\mu_{3}-\mathrm{O}\right)_{2}$

\begin{tabular}{|c|c|c|c|c|}
\hline $\begin{array}{l}\text { Com- } \\
\text { pound }\end{array}$ & $2 a$ & $2 \mathbf{b}$ & $2 c$ & $2 d$ \\
\hline $\begin{array}{l}\text { For- } \\
\text { mula }\end{array}$ & $\begin{array}{l}\mathrm{Bi}_{4} \mathrm{Co}_{1} \mathrm{C}_{32} \mathrm{H}_{18} \\
\mathrm{~F}_{30} \mathrm{~N}_{6} \mathrm{O}_{22}\end{array}$ & $\begin{array}{l}\mathrm{Bi}_{4} \mathrm{Co}_{1} \mathrm{C}_{34} \mathrm{H}_{25} \\
\mathrm{~F}_{30} \mathrm{~N}_{2} \mathrm{O}_{27}\end{array}$ & $\begin{array}{l}\mathrm{Bi}_{4} \mathrm{Cu}_{2} \mathrm{C}_{36} \mathrm{H}_{24} \\
\mathrm{~F}_{30} \mathrm{~N}_{8} \mathrm{O}_{22}\end{array}$ & $\begin{array}{l}\mathrm{Bi}_{4} \mathrm{C}_{28} \mathrm{H}_{24} \mathrm{~F} \\
{ }_{30} \mathrm{~N}_{2} \mathrm{O}_{22}\end{array}$ \\
\hline $\begin{array}{l}\text { Crys- } \\
\text { tal } \\
\text { Sys- } \\
\text { tem }\end{array}$ & Monoclinic & Monoclinic & Triclinic & Triclinic \\
\hline $\begin{array}{l}\text { Space } \\
\text { Group }\end{array}$ & $\mathrm{P}_{2} / \mathrm{c}$ & $\mathrm{P}_{2_{1}} / \mathrm{c}$ & $\mathrm{P} \overline{1}$ & $\mathrm{P} \overline{1}$ \\
\hline $\mathrm{a}, \AA$ & $11.538(2)$ & $11.382(4)$ & $10.054(3)$ & $9.429(3)$ \\
\hline $\mathrm{b}, \AA$ & $24 \cdot 701(4)$ & $22.180(7)$ & $12.970(4)$ & $13.001(5)$ \\
\hline c, $\AA$ & $21.852(4)$ & $15.021(5)$ & $15.295(5)$ & $13.971(5)$ \\
\hline$\alpha$ & 90 & 90 & $104.175(4)$ & $113.359(5)$ \\
\hline$\beta$ & $99 \cdot 324$ & $94.319(4)$ & $103 \cdot 337(3)$ & $96.626(2)$ \\
\hline$\gamma$ & 90 & 90 & $90.7910(10)$ & $96.678(3)$ \\
\hline V & $6145.8(19)$ & $3781(2)$ & $1876.4(10)$ & 1536.9(9) \\
\hline Z & 4 & 4 & 2 & 2 \\
\hline $\begin{array}{l}\mathrm{R} ; \\
\mathrm{wR2}\end{array}$ & $\begin{array}{l}0.0508 \\
0.1041\end{array}$ & $\begin{array}{l}0.0450 \\
0.095^{1}\end{array}$ & $\begin{array}{l}0.0356 \\
0.0889\end{array}$ & $\begin{array}{l}0.0404 \\
0.1182\end{array}$ \\
\hline GOF & 1.135 & 1.128 & 1.025 & 0.912 \\
\hline
\end{tabular}

Compounds $\mathbf{2 a}$ and $\mathbf{2 b}$ were synthesized using cobalt(III) acac in reaction with $\mathrm{BiPh}_{3}$ and trifluoroacetic acid in acetonitrile. The reaction mixture for $\mathbf{2 a}$ was then layered over toluene while the mixture for $\mathbf{2} \mathbf{b}$ was not. While both reactions resulted in the synthesis of similar polymeric anionic clusters, the cations in the crystal lattice differed greatly, as 2b contains a cation with tripodal ligands not previously reported which participates in a hydrogen bonded network. The structure also contains free trifluoroacetic acid in the lattice. The anion in $\mathbf{2 a}$ is balanced by a hex- 
akis(acetonitrile)cobalt(III) cation. Additionally, the asymmetric unit of the anion of $\mathbf{2 a}$ forms a 1-D polymer bridged by two trifluoroacetate ligands between two adjacent cluster units (Figure $\mathbf{2 b}$ ).

(A)

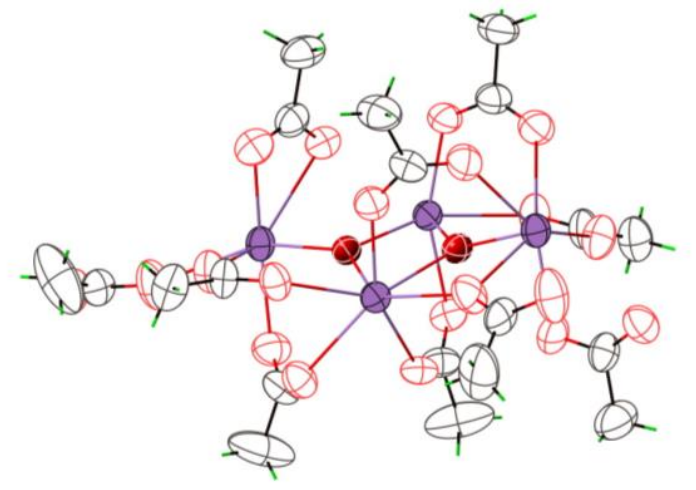

(B)

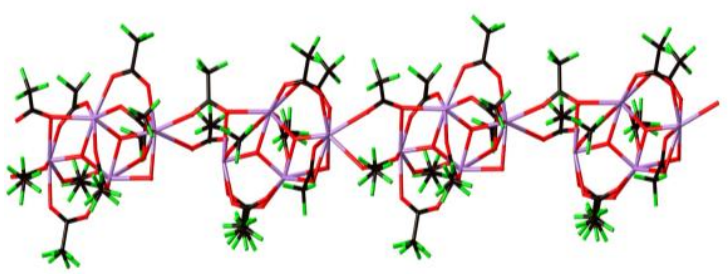

Figure 2. (A) Molecular structure of the asymmetric unit of the anion in $2 \mathrm{a}$ and (B) polymeric structure of the compound, displaying three of the monomeric asymmetric units bridged by trifluoroacetate ligands. The displacement ellipsoids for the fluorine atoms have been omitted for clarity. Some $\mathrm{CF}_{3}$ groups exhibited rotational disorder that has been omitted in (A). Bi, purple; $\mathrm{O}$, red; C, black; F, green.

Compound $\mathbf{2 b}$ crystallizes with a cobalt countercation coordinated to a pair of tripodal ligands, $\left[\mathrm{Co}\left\{\mathrm{HC}(\mathrm{MeCO})_{2}(\mathrm{MeCNH})\right\}_{2}\right]^{3+}$ (Figure 3). The $\mathrm{O}$ and $\mathrm{NH}$ positions of the cation were disordered and refined as a statistical mixture of $2 / 3 \mathrm{O}$ and $1 / 3 \mathrm{NH}$ at each site. The $\mathrm{H}$ atom was included in calculated positions at $1 / 3$ occupancy on each of these sites. The tripodal ligand is expected to form by coupling of an acetylacetonate ligand bound to cobalt with a molecule of acetonitrile to form $\beta$ enaminodione ligands by a mechanism similar previously reported in the synthesis of related compounds from malononitrile $\left(\mathrm{NCCH}_{2} \mathrm{CN}\right)$ (Equation 2). ${ }^{66}$ This process is most likely initiated by removal of an acac ligand from $\mathrm{Co}(\mathrm{acac})_{3}$ via protonation with trifluoroacetic acid. Similar processes at $\mathrm{Co}(\mathrm{acac})_{3}$ in the presence of trifluoroacetic acid are known to proceed via radical mechanisms and can lead to reduction of cobalt, but we believe that the final cation retains the $\mathrm{Co}^{3+}$ oxidation state in this case. This hypothesis is supported by the observation that reaction of $\mathrm{Bi}\left(\mathrm{NO}_{3}\right)_{3} \cdot \mathrm{H}_{2} \mathrm{O}$ with $\mathrm{Co}(\mathrm{acac})_{3}$ in $\mathrm{MeCN}$ produces the same cation with the previously unknown hexanitratobismuth(III) anion, $\left[\mathrm{Bi}\left(\mathrm{NO}_{3}\right)_{6}\right]^{3-}$ (Figure 4, 3). In this case, there is no question about the oxidation states of the metals involved since a $2+$ counterion would require $B i$ to be +4 , which is an unknown oxidation state for that element. The $\left[\mathrm{Bi}\left(\mathrm{NO}_{3}\right)_{6}\right]^{3-}$ has not been previously observed. It possesses non-crystallographic $C_{2}$ symmetry with four bidentate and two monodentate nitrate ligands. Additionally, the bond lengths of the cation in both compounds are similar, with the average Co-( $\mathrm{N}, \mathrm{O})$ bond distances in $\mathbf{2 b}$ and $\mathbf{3}$ are $1.906(8)$ and 1.913(6), respectively. Similar coordinating ligands have also been synthesized following the $\beta$ enaminodione structure, but bound to metals at only one imino and one carbonyl site, as opposed to the tridentate bonding seen here. ${ }^{67}$

(A)

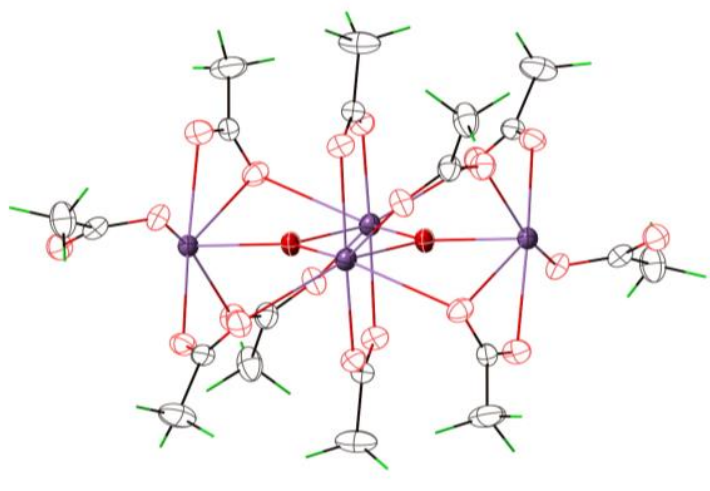

(B)

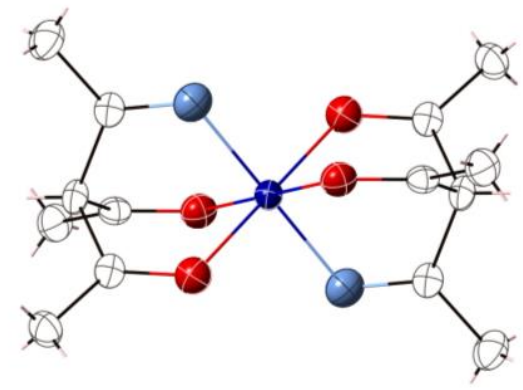

(C)

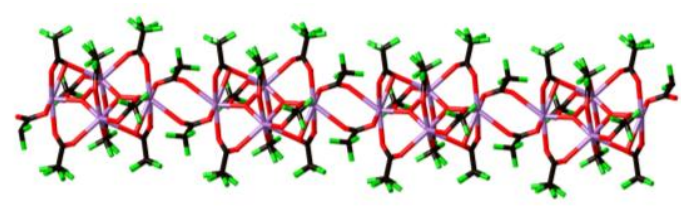

Figure 3. Molecular structure for (A) the anion, (B) cation, and $(\mathrm{C})$ polymeric structure in $\mathbf{2 b}$. The displacement ellipsoids for the fluorine atoms have been omitted for clarity. $\mathrm{Bi}$, purple; O, red; C, black; F, green; N, light blue; Co, dark blue. Some $\mathrm{CF}_{3}$ groups exhibited rotational disorder that has been omitted in (A).<smiles>C#CC(C)(C)CCC(=O)C(N)C(C)=O</smiles> 
(A)

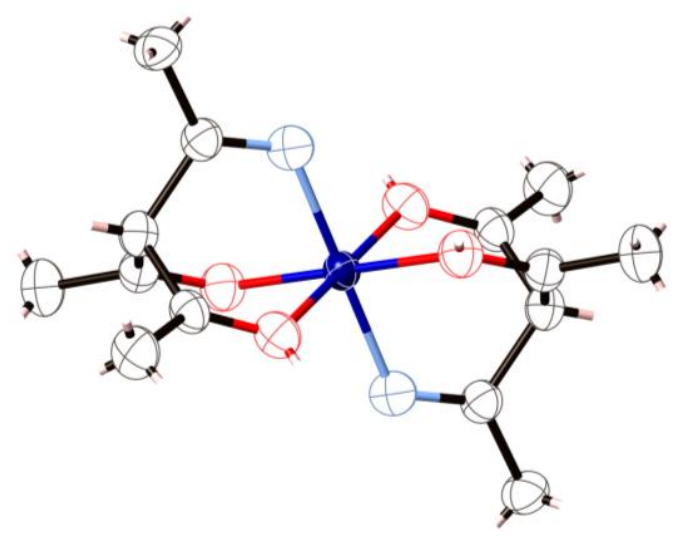

(B)

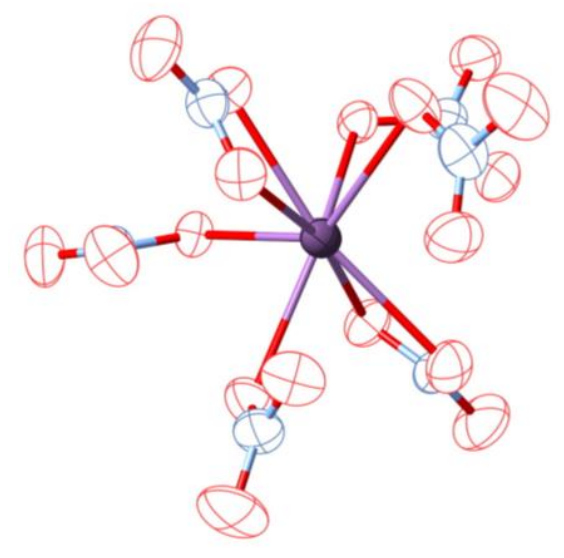

Figure 4. Molecular structure for the (A) cation and (B) anion in $\left[\left(\mathrm{HC}\{\mathrm{MeCO}\}_{2}\{\mathrm{MeCNH}\}\right)_{2} \mathrm{Co}\right]\left[\mathrm{Bi}\left(\mathrm{NO}_{3}\right)_{6}\right]$. Bi, purple; $\mathrm{O}$, red; $\mathrm{N}$, light blue; $\mathrm{Co}$, dark blue.

Compound $\mathbf{2 c}$ was synthesized in a similar fashion using copper(I) oxide as the metal ion source. This compound also crystallizes as a polymer, with each asymmetric unit bridged by two trifluoroacetate ligands between adjacent units (Figure 5). Compound $2 \mathbf{d}$ was synthesized by applying the same synthetic method with an organic cation. For this reaction tetramethylammonium hydroxide was added to the solution of $\mathrm{BiPh}_{3}$ and trifluoroacetic acid in acetonitrile (Figure 6).

The formation of these bismuth-oxido cluster compounds tentatively follow a similar formation mechanism as summarized in Equation 3. The trifluoroacetic acid added to the solution can displace the weakly bound phenyl ligands in $\mathrm{BiPh}_{3}$ through protonation and benzene elimination. This leads to the formation of a trifluoroacetate species such as $\mathrm{Bi}\left(\mathrm{O}_{2} \mathrm{CCF}_{3}\right)_{3}{ }^{50}$ which can undergo hydrolysis (Scheme 1). It is anticipated that the simple $\mu-\mathrm{O}$ configuration in $\left(\mathrm{CF}_{3} \mathrm{CO}_{2}\right)_{2} \mathrm{Bi}-\mathrm{O}-\mathrm{Bi}\left(\mathrm{O}_{2} \mathrm{CCF}_{3}\right)_{2}$ would be less stable than the $\mu_{3}-\mathrm{O}$ configuration, which would promote dimerization of these $\mathrm{Bi}_{2} \mathrm{O}$ fragments. A compound with a $\mathrm{Bi}_{2} \mathrm{O}$ core is known but it is stabilized by bulky calixarene ligands. ${ }^{8}$ These anions are all charge-balanced by cationic transition metal species. The cations found here are conventional. The cobalt hexakis(acetonitrile) $\left[\mathrm{Co}(\mathrm{NCMe})_{6}\right]^{2+}$ cation seen in $\mathbf{2 a}$ is known to crystallize with smallmolecule anions. ${ }^{68-71}$ Other cobalt and nickel cations have been seen to crystallize with large antimony oxoclusters. $^{72,73}$ The copper (I) cation $\left[\mathrm{Cu}(\mathrm{NCMe})_{4}\right]^{+}$in $\mathbf{2 c}$ is a well-known. ${ }^{74-80}$ The cuprous oxide used in the synthesis of 2c provides an easy way to obtain the $\mathrm{Cu}^{+}$ion in solution (Equation 4) ${ }^{81}$ The ${ }^{19} \mathrm{~F}$ NMR spectrum of the $\mathrm{Bi}_{4} \mathrm{O}_{2}$ clusters showed only one fluorine resonance, indicating that the trifluoroacetate ligands are exchanging on the NMR timescale . No other fluorine-containing compound was observed by NMR in these samples.

(A)

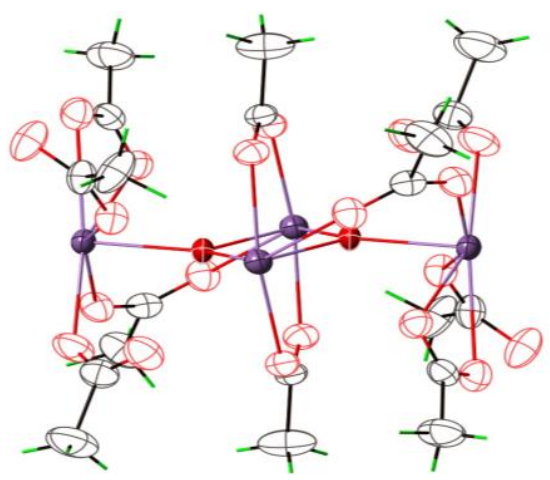

(B)

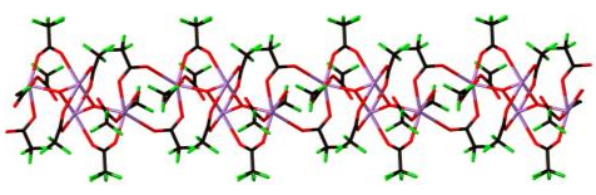

Figure 5. Molecular structure for (A) the asymmetric portion of the anion for $\mathbf{2} \mathbf{c}$ and (B) a representation of the polymeric structure. The displacement ellipsoids for the fluorine atoms have been omitted for clarity. $\mathrm{Bi}$, purple; $\mathrm{O}$, red; C, black; F, green.

(A)

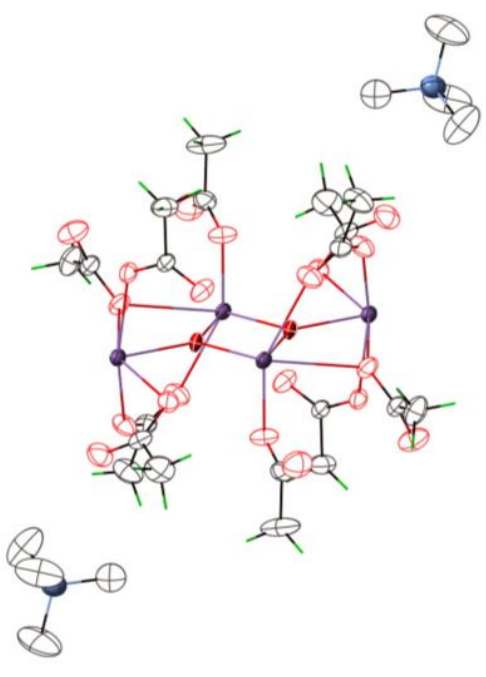


(B)

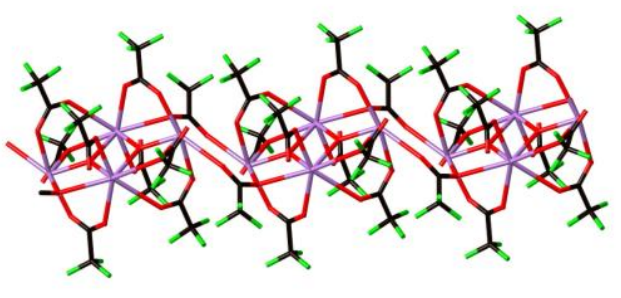

Figure 6. Molecular structure for (A) the asymmetric portion of the anion for $\mathbf{2 d}$ and (B) a representation of the polymeric structure. The displacement ellipsoids for the fluorine atoms have been omitted for clarity. $\mathrm{Bi}$, purple; $\mathrm{O}$, red; $\mathrm{C}$, black; F, green; $\mathrm{Cu}$, blue.

$$
\begin{aligned}
& 4 \mathrm{BiPh}_{3}+8 \mathrm{CF}_{3} \mathrm{CO}_{2} \mathrm{H}+2 \mathrm{CF}_{3} \mathrm{CO}_{2}^{-}+2 \mathrm{H}_{2} \mathrm{O} \rightarrow \\
& {\left[\mathrm{Bi}_{4} \mathrm{O}_{2}\left(\mathrm{CF}_{3} \mathrm{CO}_{2}\right)_{10}\right]^{2-}+12 \mathrm{Ph}-\mathrm{H}} \\
& \mathrm{Cu}_{2} \mathrm{O}+2 \mathrm{CF}_{3} \mathrm{CO}_{2} \mathrm{H}+8 \mathrm{MeCN} \rightarrow \\
& 2[\mathrm{Cu}(\mathrm{NCMe})]_{4}\left[\mathrm{CF}_{3} \mathrm{CO}_{2}\right]+\mathrm{H}_{2} \mathrm{O} \\
& \mathrm{Bi}\left(\mathrm{O}_{2} \mathrm{CCF}_{3}\right)_{3} \underset{-\mathrm{CF}_{3} \mathrm{CO}_{2} \mathrm{H}}{\stackrel{+\mathrm{H}_{2} \mathrm{O}}{\longrightarrow}}\left(\mathrm{CF}_{3} \mathrm{CO}_{2}\right)_{2} \mathrm{Bi}-\mathrm{OH} \underset{-\mathrm{CF}_{3} \mathrm{CO}_{2} \mathrm{H}}{\stackrel{+\mathrm{Bi}\left(\mathrm{O}_{2} \mathrm{CCF}_{3}\right)_{3}}{\longrightarrow}}\left(\mathrm{CF}_{3} \mathrm{CO}_{2}\right)_{2} \mathrm{Bi}-\mathrm{O}-\mathrm{Bi}_{2}\left(\mathrm{O}_{2} \mathrm{CCF}_{3}\right)_{2}
\end{aligned}
$$

Scheme 1. Possible hydrolysis of bismuth trifluoroacetate leading to the $\mathrm{Bi}_{4} \mathrm{O}_{2}$ core.

Several examples of neutral carboxylate-based $\mathrm{Bi}_{4} \mathrm{O}_{2}$ cluster compounds have been reported. These include $\left.\mathrm{Bi}_{4} \mathrm{O}_{2}\left(\mathrm{O}_{2} \mathrm{CC}_{6} \mathrm{H}_{2} \mathrm{~F}_{3}-3,4,5\right)\right)_{8} \cdot 2\left(\eta^{6}-\mathrm{C}_{6} \mathrm{H}_{6}\right),{ }^{14,82} \quad \mathrm{Bi}_{4} \mathrm{O}_{2}\left(\mathrm{O}_{2} \mathrm{CC}_{6} \mathrm{H}_{2} \mathrm{~F}_{3}-\right.$ $3,4,5)_{8} \cdot 2\left(\mathrm{C}_{6} \mathrm{H}_{4} \mathrm{Me}_{2}-1,4\right),{ }^{1,42} \quad\left[\mathrm{Bi}_{4} \mathrm{O}_{2}\left(\mathrm{OSiEt}_{3}\right)_{8}\right]^{7}$ and $\left[\mathrm{Bi}_{4}\left(\mu_{3}-\right.\right.$ $\left.\mathrm{O})_{2}(\mathrm{HSal})_{8}\right]^{2} 2 \mathrm{solv}\left(\mathrm{solv}=\mathrm{MeCN}\right.$ or $\left.\mathrm{MeNO}_{2}\right),{ }^{32}$ $\left[\mathrm{Bi}_{4} \mathrm{O}_{2}\left\{\mathrm{OCH}\left(\mathrm{CF}_{3}\right)_{2}\right\}_{8}\left(\mathrm{Et}_{2} \mathrm{O}\right)_{2}\right],{ }^{37}\left[\mathrm{Bi}_{4} \mathrm{O}_{2}\left\{\mathrm{OCH}\left(\mathrm{CF}_{3}\right)_{2}\right\}_{8}(\mathrm{THF})\right]^{37}$ $\left[\mathrm{Bi}_{4} \mathrm{O}_{2}\left\{\mathrm{OCH}\left(\mathrm{CF}_{3}\right)_{2}\right\}_{8}(\text { tmeda })_{2}\right],{ }^{37}\left[\mathrm{Bi}_{4} \mathrm{O}_{2}\{\mathrm{HC} 8\}\right] \quad(\mathrm{HC} 8=$ $\left.\left(\mathrm{C}_{6} \mathrm{H}_{3} \mathrm{O}\right)_{8}\left(\mathrm{CH}_{2}\right)_{8}\right),{ }^{8}$ and $\left[\mathrm{Bi}_{4} \mathrm{O}_{2}\{\mathrm{BnC} 8\}\right]$ (BnC8 $=$ $\left.\left[\left(\mathrm{C}_{6} \mathrm{H}_{2} \mathrm{O}\right)\left(\mathrm{C}_{6} \mathrm{H}_{5}\right)\right]_{8}\left(\mathrm{CH}_{2}\right)_{8}\right)^{8}$ and $\mathrm{Bi}_{4} \mathrm{O}_{2}(\mathrm{OAr})_{4}\left[\mathrm{OC}_{6} \mathrm{H}_{3}\left({ }^{\mathrm{i}} \mathrm{Pr}\right)\left\{\mathrm{C}\left(\mathrm{CH}_{2}\right)_{2}\right\}\right]_{2}{ }^{83}$ The $\mathrm{Bi}_{4} \mathrm{O}_{2}$ unit is also observed bound in calixarene ligands sets and these ligands are also known to support a dimerized $\left(\mathrm{Bi}_{4} \mathrm{O}_{2}\right)_{2}$ species. ${ }^{8,84}$ These compounds can be described as "butterfly-shaped" with the two central $\mathrm{Bi}$ atoms being the hinge atoms of the butterfly and the two end $\mathrm{Bi}$ atoms as the wingtip atoms. In general for the neutral molecules, the oxide to hinge bismuth distances are longer by 0.1 to $0.2 \AA$. The difference is smaller in the anionic versions, likely because of the additional ligands attached to the wingtip atoms. Similar to the neutral compounds, the $\mu_{3}$-bridging oxide ligands in these anionic clusters are relatively planar. Three alkoxide-based $\mathrm{Bi}_{4} \mathrm{O}_{2}$ clusters have been found to bind additional alkali metal alkoxide units. These include Na$\mathrm{Bi}_{4} \mathrm{O}_{2}\left(\mathrm{OC}_{6} \mathrm{~F}_{5}\right)_{9}(\mathrm{THF})_{2},{ }^{9} \quad \mathrm{Na}_{2} \mathrm{Bi}_{4} \mathrm{O}_{2}\left(\mathrm{OC}_{6} \mathrm{~F}_{5}\right)_{10}(\mathrm{THF})_{2},{ }^{9} \quad$ and $\left[\mathrm{Li}_{2} \mathrm{Bi}_{4} \mathrm{O}_{2}\{2-2 \text {-(prop-2-enyl)phenoxo }\}_{10}\right]^{83}$ those compounds differ in that the bridging oxides interact with the $\mathrm{Li}^{+}$or $\mathrm{Na}^{+}$ions and are essentially tetrahedral as a result.

Structurally, the carboxylate ligands in the new anionic clusters have a different arrangement than that of the compounds with only eight carboxylates or alkoxides. In $\mathbf{2 a - 2 c}$ carboxylate ligands bridge the two hinge atoms, which is not seen in $\mathbf{2 d}$ or the neutral $\mathrm{Bi}_{4} \mathrm{O}_{2}$ carboxylate clusters previously reported. This could be due to the fact that the anionic structures prefer to accommodate additional ligands at the wingtip bismuth atoms, causing some carboxylates to move towards the hinge atoms. In some cases, the additional carboxylates replace coordinated solvent on the $\mathrm{Bi}_{4} \mathrm{O}_{2}$ core. The coordination number of the bismuth atoms, however, remains relatively constant, ranging from 5 to 7. A comparison of bond parameters for the newly synthesized clusters as well as neutral carboxylate clusters and oxide clusters is presented in Table 5 below.

\section{CONCLUSION}

In summary, the reaction of $\mathrm{BiPh}_{3}$ with trifluoroacetic acid and a transition metal ion source leads to the synthesis of anionic bismuth-oxido clusters with transition metalbased countercations. This not only adds to the library of carboxylate bismuth-oxido clusters, but also provides insight into a new area of chemistry, as these are some of the first systematically-prepared anionic carboxylate clusters. These clusters as well as a $\mathrm{Bi}_{4} \mathrm{O}_{2}$ trifluoroacetate cluster with an organic cation were fully characterized using $\mathrm{x}$-ray crystallography and elemental analysis. The anionic $\mathrm{Bi}_{4} \mathrm{O}_{2}$ bismuth-oxido clusters contain new bonding patterns not previously observed in neutral carboxylate species, and they should possess different solubilities and stabilities compared to the neutral complexes. These new compounds can be viewed as possible starting materials for

\begin{tabular}{|c|c|c|c|c|}
\hline Compound & $\begin{array}{l}\mathrm{dBi}_{\text {hinge }} \\
\mathrm{O}, \AA \\
\text { ave. }\end{array}$ & $\begin{array}{l}\mathrm{dBi}_{\text {wingtip- }} \\
\mathrm{O}, \AA \\
\text { ave. }\end{array}$ & $\begin{array}{l}\Sigma<\mathrm{Bi}- \\
\mathrm{O}_{\text {oxide }}-\mathrm{Bi} \\
{ }^{2}\end{array}$ & Ref \\
\hline $2 a$ & 2.166 & 2.135 & 359.00 & \\
\hline $\mathbf{2 b}$ & 2.170 & 2.140 & 359.96 & \\
\hline $2 \mathrm{c}$ & 2.170 & 2.128 & 358.11 & \\
\hline 2d & 2.164 & 2.101 & 359.84 & \\
\hline $\begin{array}{l}\mathrm{Bi}_{4} \mathrm{O}_{2}\left(\mathrm{O}_{2} \mathrm{CC}_{6} \mathrm{H}_{2} \mathrm{~F}_{3}-\right. \\
3,4,5)_{8} \cdot 2\left(\eta 6-\mathrm{C}_{6} \mathrm{H}_{6}\right)\end{array}$ & 2.197 & 2.094 & 356.10 & 14,82 \\
\hline $\begin{array}{l}\mathrm{Bi}_{4} \mathrm{O}_{2}\left(\mathrm{O}_{2} \mathrm{CC}_{6} \mathrm{H}_{2} \mathrm{~F}_{3}-\right. \\
3,4,5)_{8} \cdot 2\left(\mathrm{C}_{6} \mathrm{H}_{4} \mathrm{Me}_{2}-1,4\right)\end{array}$ & 2.200 & 2.089 & 356.45 & 14,82 \\
\hline $\mathrm{Bi}_{4} \mathrm{O}_{2}\left(\mathrm{OSiEt}_{3}\right)_{8}$ & 2.254 & 2.045 & 338.20 & 7 \\
\hline $\begin{array}{l}{\left[\mathrm{Bi}_{4}\left(\mu_{3^{-}}\right.\right.} \\
\left.\mathrm{O})_{2}(\mathrm{HSal})_{8}\right] .2 \mathrm{MeCN}\end{array}$ & 2.206 & 2.085 & $357 \cdot 34$ & 32 \\
\hline $\begin{array}{l}{\left[\mathrm{Bi}_{4}\left(\mu_{3^{-}}\right.\right.} \\
\left.\mathrm{O})_{2}(\mathrm{HSal})_{8}\right] .2 \mathrm{MeNO}_{2}\end{array}$ & 2.196 & 2.091 & $357 \cdot 79$ & 32 \\
\hline $\mathrm{Bi}_{4} \mathrm{O}_{2}\left\{\mathrm{OCH}\left(\mathrm{CF}_{3}\right)_{2}\right\}_{8}\left(\mathrm{Et}_{2} \mathrm{O}\right)_{2}$ & 2.159 & 2.108 & 356.73 & 37 \\
\hline $\mathrm{Bi}_{4} \mathrm{O}_{2}\left\{\mathrm{OCH}\left(\mathrm{CF}_{3}\right)_{2}\right\}_{8}$ (THF) & 2.156 & 2.102 & 357.69 & 37 \\
\hline $\mathrm{Bi}_{4} \mathrm{O}_{2}\{\mathrm{HC} 8\}$ & 2.288 & 2.109 & 340.08 & 8 \\
\hline $\mathrm{Bi}_{4} \mathrm{O}_{2}\{\mathrm{BnC} 8\}$ & 2.277 & 2.120 & 341.72 & 8 \\
\hline $\begin{array}{l}\mathrm{Bi}_{4} \mathrm{O}_{2}(\mathrm{Oar})_{4}\left[\mathrm{OC}_{6} \mathrm{H}_{3}(\mathrm{iPr})\right. \\
\left.\left\{\mathrm{C}\left(\mathrm{CH}_{2}\right)_{2}\right\}\right]_{2}\end{array}$ & 2.201 & 2.063 & 356.61 & 83 \\
\hline $\mathrm{NaBi}_{4} \mathrm{O}_{2}\left(\mathrm{OC}_{6} \mathrm{~F}_{5}\right)_{9}(\mathrm{THF})_{2}$ & 2.191 & 2.042 & 355.20 & 9 \\
\hline
\end{tabular}
further cluster growth towards previously unobserved nuclearities.

Table 5. A comparison of select bond parameters for the $\mathrm{Bi}_{4} \mathrm{O}_{2}$ oxido clusters. 


$\begin{array}{lllll}\mathrm{Na}_{2} \mathrm{Bi}_{4} \mathrm{O}_{2}\left(\mathrm{OC}_{6} \mathrm{~F}_{5}\right)_{10}(\mathrm{THF})_{2} & 2.185 & 2.150 & 336.90 & 9 \\ \mathrm{Bi}_{4} \mathrm{O}_{2}\left\{\mathrm{tBuC}_{7}(\mathrm{H})_{3}\right\}_{2} & 2.197 & 2.175 & 336.12 & 8 \\ \mathrm{Bi}_{4} \mathrm{O}_{2}\left\{\mathrm{tBuC}_{5}(\mathrm{H})\right\}_{2} & 2.199 & 2.156 & 352.51 & 85 \\ \mathrm{Bi}_{4} \mathrm{O}_{2}\left\{\mathrm{BnC}_{5}(\mathrm{H})\right\}_{2} & 2.154 & 2.126 & 348.93 & 85 \\ \mathrm{Bi}_{4} \mathrm{O}_{2} \mathrm{R}_{\mathrm{f}}{ }^{*} & 2.225 & 2.099 & 357.34 & 86 \\ \mathrm{Li}_{2} \mathrm{Bi}_{4}\left(\mu_{3}-\mathrm{O}\right)_{2}[\mathrm{O}-2- & 2.218 & 2.076 & 357.37 & 83 \\ \left.\left(\mathrm{CH}_{2} \mathrm{CH}=\mathrm{CH}_{2}\right) \mathrm{C}_{6} \mathrm{H}_{4}\right]_{10} & & & & \\ \mathrm{Bi}_{4} \mathrm{O}_{2}\left(\mathrm{C}_{6} \mathrm{H}_{4} \mathrm{CH}_{3}\right)_{8} & 2.189 & 2.379 & 298.59 & 87 \\ \mathrm{Bi}_{4} \mathrm{O}_{2}\left(\mathrm{OCMe} \mathrm{OC}_{2} \mathrm{Pr}\right)_{8} & 2.258 & 2.080 & 340.31 & 88\end{array}$

\section{EXPERIMENTAL}

General. All reagents and chemicals, unless otherwise stated, were purchased from commercial sources. X-ray crystallography was performed on a Rigaku SCX Mini diffractometer with a Mo radiation source and a graphite monochromator. Structures were solved using the SHELXTL software package. Infrared spectra were taken in the solid state on a PerkinElmer FTIR device. Elemental analyses $(\mathrm{C}, \mathrm{H}, \mathrm{N})$ were carried out at Galbraith Laboratories..

\section{Syntheses}

Synthesis of $\left[\mathrm{Ni}\left(\mathrm{H}_{2} \mathrm{O}\right)_{4}(\mathrm{NCMe})_{2}\right]\left[\mathrm{Bi}_{6} \mathrm{O}_{4}(\mathrm{OH})_{4}\left(\mathrm{CF}_{3} \mathrm{CO}_{2}\right)_{12}\right]$, $\mathbf{1 a}$ : Triphenylbismuth $(0.22 \mathrm{~g}, 0.50 \mathrm{mmol})$ was dissolved in $5 \mathrm{~mL}$ of acetonitrile in a $20 \mathrm{~mL}$ scintillation vial. To this solution 0.075 $\mathrm{mL}$ of trifluoroacetic acid (1.0 mmol) was added. This gave a light yellow solution. Nickel formate ( $0.146 \mathrm{~g}$, $0.99 \mathrm{mmol}$ ) was added and the vial was sonicated until most solids had dissolved, giving a green-blue solution. This solution was left to stand for two days. After gravity filtration, the solution was left to evaporate slowly. After two weeks, cubic colorless crystals suitable for single crystal X-ray diffraction developed on the walls of the vial. Yield: $40 \%$. Anal. Found for 1a: 11.60 ; $\mathrm{H}$ : 0.63 ; N1.03. Calculated for $\mathrm{CoBi}_{6} \mathrm{C}_{28} \mathrm{H}_{19} \mathrm{~N}_{2} \mathrm{O}_{36} \mathrm{~F}_{36}$ (\%) C11.38; H o.61; N 0.95

Synthesis of $\left[\mathrm{Co}\left(\mathrm{H}_{2} \mathrm{O}\right)_{4}(\mathrm{NCMe})_{2}\right]\left[\mathrm{Bi}_{6} \mathrm{O}_{4}(\mathrm{OH})_{4}\left(\mathrm{CF}_{3} \mathrm{CO}_{2}\right)_{12}\right], \mathbf{l} \boldsymbol{b}$ : Triphenylbismuth $(0.22 \mathrm{~g}, 0.50 \mathrm{mmol})$ was dissolved in $5 \mathrm{~mL}$ of acetonitrile) in a $20 \mathrm{~mL}$ scintillation vial. To this solution 0.075 $\mathrm{mL}$ of trifluoroacetic acid (1.0 mmol) was added beneath the surface and swirled until uniformly dispersed. This gave a light yellow solution. Cobalt acetate tetrahydrate (o.2476 g, 0.99 mmol) was added and the solution vial was sonicated for roughly ten minutes until all solids had dissolved, giving a deep pink solution. The vial's cap was opened slightly and the solution was left to evaporate. After 2 weeks, pink, cubic crystals suitable for single crystal X-ray diffraction had formed along the lower walls and base of the vial. These were confirmed by X-Ray diffraction to be $\mathbf{1 b}$. Anal. Found for $\mathbf{1 b}$ : $\mathrm{C}$ 11.35; $\mathrm{H}$ o.73; $\mathrm{N}$ o.90; Calculated for $\mathrm{NiBi}_{6} \mathrm{C}_{28} \mathrm{H}_{19} \mathrm{~N}_{2} \mathrm{O}_{36} \mathrm{~F}_{36}$ (\%): $\mathrm{C}$ 11.38; H o.61; N 0.95. FT-IR( $\left.\mathrm{cm}^{-1}\right)$ : $1642(\mathrm{~m}, \mathrm{~b}), 1449(\mathrm{w}), 1190(\mathrm{~s})$, 1153(s), 854(w), 794(m), 725(s).

Synthesis of $\left\{\left[\mathrm{Co}(\mathrm{NCMe})_{6}\right]\left[\mathrm{Bi}_{4}\left(\mu_{3}-\mathrm{O}\right)_{2}\left(\mathrm{O}_{2} \mathrm{CCF}_{3}\right)_{10}\right]\right\}_{n}$, 2a. Triphenylbismuth (0.2213g, $0.50 \mathrm{mmol})$ was dissolved in $5 \mathrm{~mL}$ of undistilled acetonitrile. Trifluoroacetic acid (o.40 mL, 5.33 mmol) was added, and the solution was mixed gently to again give a pale yellow solution. To this was added $0.0900 \mathrm{~g}$ of co- balt (III) acetylacetonate $(0.25 \mathrm{mmol})$, and the solution was swirled briefly until the metal complex was dissolved. This solution was layered above $6 \mathrm{~mL}$ toluene, and was left to stand. After a few days, brownish-pink rectangular prismatic crystals grew on the bottom of the reaction vial, and after a few more days smaller, similarly shaped crystals started to grow on the vial walls as well. These rod-like crystals were found to be $\mathbf{2 a}$. Yield: 54\%. Anal. Found for 2a: C 16.72; $\mathrm{H} \mathrm{1.17}$; N 3.29; Calculated for $\mathrm{CoBi}_{4} \mathrm{C}_{32} \mathrm{H}_{18} \mathrm{~N}_{6} \mathrm{O}_{22} \mathrm{~F}_{30}$ (\%): $\mathrm{C}$ 16.69; $\mathrm{H}$ o.79; $\mathrm{N}$ 3.65. FTIR $\left(\mathrm{cm}^{-1}\right): 1644(\mathrm{~s}, \mathrm{~b}), 1444(\mathrm{~m}), 1184(\mathrm{~s}), 1143(\mathrm{~s}), 856(\mathrm{w}), 794(\mathrm{~m})$, $725(\mathrm{~s})$.

Synthesis of $\left\{\left[\mathrm{Co}\left\{\mathrm{HC}(\mathrm{MeCO})_{2}(\mathrm{MeCNH})\right\}_{2}\right]\left[\mathrm{Bi}_{4} \mathrm{O}_{2}\left(\mathrm{CF}_{3} \mathrm{CO}_{2}\right)_{10}\right]\right.$. $\left.{ }_{2}\left[\mathrm{CF}_{3} \mathrm{CO}_{2}\right] \cdot 2\left[\mathrm{CF}_{3} \mathrm{CO}_{2} \mathrm{H}\right] \cdot 2\left[\mathrm{H}_{2} \mathrm{O}\right]\right\}_{n}, \mathbf{2 b}$. Triphenylbismuth (o.1470 $\mathrm{g}, \quad 0.34 \mathrm{mmol})$ and $0.0886 \mathrm{~g}$ of cobalt(III) acetylacetonate (o.25 mmol) were combined in a $20 \mathrm{~mL}$ scintillation vial. To this was added $6 \mathrm{~mL}$ of acetonitrile and $0.225 \mathrm{~mL}$ of trifluoroacetic acid $(3 \mathrm{mmol})$. The vial was sonicated until the solids dissolved and then left to evaporate slowly with the cap loosened. About a month later, it was observed that colorless, rectangular prismatic crystals had formed from the thick, brown liquid that remained at the bottom of the vial. These crystals were identified by single crystal X-ray diffraction. The crystals were washed with diethyl ether. Yield: $30 \%$. Anal. Found for 2b: $\mathrm{C}$ 17.17; $\mathrm{H}$ 1.22; $\mathrm{N}$ 1.23; Calculated for $\mathrm{CoBi}_{4} \mathrm{C}_{42} \mathrm{H}_{28} \mathrm{~N}_{2} \mathrm{O}_{36} \mathrm{~F}_{42}$ (\%): $\mathrm{C} 17.83 ; \mathrm{H}$ 1.00; $\mathrm{N}$ 0.99. The analyses suggest that the compound has picked up additional water. Calculated for 3 additional water molecules: $\mathrm{CoBi}_{4} \mathrm{C}_{42} \mathrm{H}_{34} \mathrm{~N}_{2} \mathrm{O}_{39} \mathrm{~F}_{42}(\%)$ : $\mathrm{C}$ 17.49; H 1.19; N o.97. FT-IR $\left(\mathrm{cm}^{-1}\right)$ : 166o(s,b), $1437(\mathrm{w}), 1263(\mathrm{w}), 1187(\mathrm{~s})$, 1139(s), 1059(m,b), $1029(\mathrm{~m}, \mathrm{~b}), 850(\mathrm{w}), 794(\mathrm{~s}), 724(\mathrm{~s})$.

Synthesis of $\quad\left\{\left[\mathrm{Cu}(\mathrm{NCMe})_{4}\right]_{2}\left[\mathrm{Bi}_{4}\left(\mu_{3}-\right.\right.\right.$ $\left.\left.\mathrm{O})_{2}\left(\mathrm{C}_{2} \mathrm{~F}_{3} \mathrm{O}_{2}\right)_{10}\right] \cdot 2\left[\mathrm{CF}_{3} \mathrm{CO}_{2} \mathrm{H}\right]\right\}_{n}$, 2c. Triphenylbismuth (o.2204 g, $0.50 \mathrm{mmol})$ and $0.0702 \mathrm{~g}$ of $\mathrm{Cu}_{2} \mathrm{O}(0.49 \mathrm{mmol})$ were combined in a vial with $4 \mathrm{~mL}$ of acetonitrile. This solution was sonicated for several minutes until the solution turned from blue with the purple-red $\mathrm{Cu}_{2} \mathrm{O}$ solid present to a clear yellow solution with grey solid on the bottom. Trifluoroacetic acid $(0.20 \mathrm{~mL}$, $2.7 \mathrm{mmol}$ ) was added and the vial swirled to combine all constituents. The solution was left to evaporate, and yielding large, sheet-like, colorless crystals after eleven days, with a brown, syrupy liquid in the bottom of the vial. These crystals were washed with diethyl ether to remove impurities and were determined to be $\mathbf{2 c}$ by single crystal X-ray diffraction.. Yield: $80 \%$. FT-IR $\left(\mathrm{cm}^{-1}\right): \quad 1640(\mathrm{~m}, \mathrm{~b}), \quad 1446(\mathrm{w}), \quad 1190(\mathrm{~m}), \quad 1150(\mathrm{~m})$, 854(w), 794(w), 726(m). Anal Found for 2c: C 21.97; H 1.87; N 7.11. Calculated for $\mathrm{Cu}_{2} \mathrm{Bi}_{4} \mathrm{C}_{40} \mathrm{H}_{26} \mathrm{~N}_{8} \mathrm{OF}_{36}$ (\%): $\mathrm{C}$ 17.91; $\mathrm{H}$ o.98; $\mathrm{N}$ 4.18. Obtaining elemental analyses for this compound proved problematic because it decomposed under vacuum and so samples could not be completely dried. Even though no solvent was found in the crystal lattice, it is possible that disordered $\mathrm{MeCN}$ was present, which was indicated by duplicate analyses that were always found to be $\mathrm{N}$-rich. Calculated values including residual $7 \mathrm{MeCN}$ gave reasonable agreement (\%): $\mathrm{C}$ 21.85; H 1.60; N 7.08.

Synthesis of of $\left\{\left[\mathrm{Me}_{4} \mathrm{~N}_{2}\left[\mathrm{Bi}_{4}\left(\mu_{3}-\mathrm{O}\right)_{2}\left(\mathrm{C}_{2} \mathrm{~F}_{3} \mathrm{O}_{2}\right)_{10}\right] \cdot 2\left[\mathrm{CF}_{3} \mathrm{CO}_{2} \mathrm{H}\right]\right\}_{n}\right.$, 2d. Tetramethylammonium hydroxide pentahydrate (o.100 g, $0.55 \mathrm{mmol})$ and $0.472 \mathrm{~g}$ of triphenylbismuth $(1.07 \mathrm{mmol})$ were dissolved in $20 \mathrm{~mL}$ of acetonitrile. Trifluoroacetic acid (o.17 $\mathrm{mL}, 2.0 \mathrm{mmol}$ ) was added to this solution, which was then stirred overnight. The resulting solution was concentrated using a vacuum pump and crystals grew out of this concentrated solution. There were identified as $\mathbf{2 d}$ by single crystal X-ray diffraction. Yield: $87 \%$. Anal. Found for 2d: $\mathrm{C} 16.43 ; \mathrm{H} \mathrm{1.30}$; N 1.29; Calculated for $\mathrm{Bi}_{4} \mathrm{C}_{32} \mathrm{H}_{26} \mathrm{~N}_{2} \mathrm{O}_{26} \mathrm{~F}_{36}(\%)$ : $\mathrm{C}$ 16.19; $\mathrm{H} 1.10$; $\mathrm{N} 1.18$. 
Synthesis of $\left[\mathrm{Co}\left\{\mathrm{HC}(\mathrm{MeCO})_{2}(\mathrm{MeCNH})\right\}_{2}\right]\left[\mathrm{Bi}\left(\mathrm{NO}_{3}\right)_{6}\right]$, 3. Bismuth nitrate pentahydrate $(0.240 \mathrm{~g}, 0.49 \mathrm{mmol})$ and $.089 \mathrm{~g}$ of cobalt(III) acetylacetonate $(.25 \mathrm{mmol})$ were dissolved in $10 \mathrm{~mL}$ of acetonitrile. The solution was stirred overnight, and let to stand. After 2 days, crystals had appeared at the bottom of the reaction vessel, which were identified as 3 by single crystal Xray diffraction. Yield: $47 \%$. Anal. Found for 2d: C 17.88; H 2.30; $\mathrm{N}$ 11.92; Calculated for $\mathrm{CoBiC}_{14} \mathrm{H}_{22} \mathrm{~N}_{8} \mathrm{O}_{22}$ (\%): $\mathrm{C}$ 18.23; $\mathrm{H}$ 2.40; $\mathrm{N}$ 12.15 .

\section{ASSOCIATED CONTENT}

\section{Supporting Information}

The Supporting Information is available free of charge on the

\section{ACS Publications website at DOI:XXXXXXX}

Labeled anisotropic displacement ellipsoid plots, selected bond angles and distances for all compounds

\section{AUTHOR INFORMATION}

Corresponding Author

*E-mail:whitmir@rice.edu

Notes: The authors declare no competing financial interest.

\section{ACKNOWLEDGMENTS}

We would like to thank the Welch Foundation (C-0976) and the Paul \& Daisy Soros Fellowship for New Americans (IILF) and the International Research Support Initiative Program of Pakistan (SA) for their support.

\section{REFERENCES}

(1) Suzuki, H.; Komatsu, N.; Ogawa, T.; Marafuji, T.; Ikegami, T.; Matano, Y. Organobismuth Chemistry, 1st ed.; Elsevier Science, 2001.

(2) Sadler, P. J.; Sun, H.; Li, H. Bismuth(III) Complexes of the Tripeptide Glutathione ( $\gamma$-L-Glu-L-Cys-Gly). Chem. - Eur. J. 1996, 2 (6), 701-708.

(3) Andrews, P. C.; Deacon, G. B.; Forsyth, C. M.; Junk, P. C.; Kumar, I.; Maguire, M. Towards a Structural Understanding of the Anti-Ulcer and Anti-Gastritis Drug Bismuth Subsalicylate. Angew. Chem. Int. Ed. 2006, 45 (34), 5638-5642.

(4) Keogan, D. M.; Griffith, D. M. Current and Potential Applications of Bismuth-Based Drugs. Molecules 2014, 19 (9), 15258-15297.

(5) Yang, N.; Sun, H. Biocoordination Chemistry of Bismuth: Recent Advances. Coord. Chem. Rev. 2007, 251 (17-20), 2354-2366.

(6) Hanna, T. A. The Role of Bismuth in the SOHIO Process. Coord. Chem. Rev. 2004, 248 (5-6), 429-440.

(7) Mehring, M.; Mansfeld, D.; Paalasmaa, S.; Schürmann, M. Polynuclear Bismuth-Oxo Clusters: Insight into the Formation Process of a Metal Oxide. Chem. - Eur. J. 2oo6, 12 (6), 1767-1781.

(8) Mendoza-Espinosa, D.; Rheingold, A. L.; Hanna, T. A. Synthesis of Bismuth and Antimony Complexes of the "Larger" Calix[n]arenes ( $\mathrm{n}=6-8)$; from Mononuclear to Tetranuclear Complexes. Dalton Trans. Camb. Engl. 2003 2009, No. 26, 5226-5238.

(9) Whitmire, K. H.; Hoppe, S.; Sydora, O.; Jolas, J. L.; Jones, C. M. Oligomerization and Oxide Formation in Bismuth Aryl Alkoxides: Synthesis and Characterization of $\mathrm{Bi}_{4}\left(\mu_{4}-\mathrm{O}\right)\left(\mu-\mathrm{OC}_{6} \mathrm{~F}_{5}\right)_{6}\left(\mu_{3}-\mathrm{OBi}(\mu-\right.$ $\left.\left.\mathrm{OC}_{6} \mathrm{~F}_{5}\right)_{3}\right)_{2}\left(\mathrm{C}_{6} \mathrm{H}_{5} \mathrm{CH}_{3}\right), \quad \mathrm{Bi}_{8}\left(\mu_{4}-\mathrm{O}\right)_{2}\left(\mu_{3}-\mathrm{O}\right)_{2}\left(\mu-\mathrm{OC}_{6} \mathrm{~F}_{5}\right)_{16}$,
$\mathrm{Bi}_{6}\left(\mu_{3}-\mathrm{O}\right)_{4}\left(\mu_{3}-\mathrm{OC}_{6} \mathrm{~F}_{5}\right)\left(\mu_{3}-\mathrm{OBi}\left(\mathrm{OC}_{6} \mathrm{~F}_{5}\right)_{4}\right)_{3}, \quad \mathrm{NaBi}_{4}\left(\mu_{3}-\right.$ $\mathrm{O})_{2}\left(\mathrm{OC}_{6} \mathrm{~F}_{5}\right)_{9}(\mathrm{THF})_{2}$, and $\mathrm{Na}_{2} \mathrm{Bi}_{4}\left(\mu_{3}-\mathrm{O}\right)_{2}\left(\mathrm{OC}_{6} \mathrm{~F}_{5}\right)_{10}(\mathrm{THF})_{2}$. Inorg. Chem. 2000, 39 (1), 85-97.

(10) Kugel, B.; Frank, W. Basische Schichten- Und Raumnetzcarboxylate Des Bismuts. Z. Für Anorg. Allg. Chem. 2002, 628 (9-10), 2178-2178.

(11) Liu, B.; Zhou, W.-W.; Zhou, Z.-Q.; Zhang, X.-Y. Hydrolysis to the First Dumbbell-like High-Nuclearity Bismuth-Oxo Cluster $\left[\mathrm{Bi}_{12}\left(\mu_{3}-\mathrm{OH}\right)_{4}\left(\mu_{2}-\mathrm{OH}\right)_{2}\left(\mu_{3}-\mathrm{O}\right)_{8}\left(\mu_{4}-\right.\right.$ $\left.\mathrm{O})_{2}\left(\mathrm{NO}_{3}\right)_{6}\right]^{4+}$ : Synthesis, Structure and Spectroscopic Characterizations. Inorg. Chem. Commun. 2007, 10 (10), 1145-1148.

(12) Henry, N.; Evain, M.; Deniard, P.; Jobic, S.; Mentré, O.; Abraham, F. $\left[\mathrm{Bi}_{6} \mathrm{O}_{4.5}(\mathrm{OH})_{3.5}\right]_{2}\left(\mathrm{NO}_{3}\right)_{11}$ : A New Anhydrous Bismuth Basic Nitrate. Synthesis and Structure Determination from Twinned Crystals. J. Solid State Chem. 2003, 176 (1), 127-136.

(13) Lazarini, F. Bismuth Basic Nitrate $\left[\mathrm{Bi}_{6}\left(\mathrm{H}_{2} \mathrm{O}\right)\left(\mathrm{NO}_{3}\right) \mathrm{O}_{4}(\mathrm{OH})_{4}\right]\left(\mathrm{NO}_{3}\right)_{5}$. Acta Crystallogr. B 1979, 35 (2), 448-450.

(14) Sharutin, V. V.; Egorova, I. V.; Sharutina, O. K.; Ivanenko, T. K.; Adonin, N. Y.; Starichenko, V. F.; Pushilin, M. A.; Gerasimenko, A. V. Tetranuclear Bismuth Complexes $\mathrm{Bi}_{4}(\mathrm{O})_{2}\left(\mathrm{O}_{2} \mathrm{CC}_{6} \mathrm{H}_{2} \mathrm{~F}_{3}-3,4,5\right)_{8} \cdot{ }_{2} \mathrm{C}_{6} \mathrm{H}_{6}$ and $\mathrm{Bi}_{4}(\mathrm{O})_{2}\left(\mathrm{O}_{2} \mathrm{CC}_{6} \mathrm{H}_{2} \mathrm{~F}_{3}-3,4,5\right)_{8} \cdot 2 \mathrm{C}_{6} \mathrm{H}_{4} \mathrm{Me2}-1,4$ : Synthesis and Structures. Russ. J. Coord. Chem. 2005, 31 (1), 28.

(15) Sundvall, B. An X-Ray Diffraction Study of the Hexanuclear Complex of Bi(III) in Aqueous Perchlorate Solution. Determination of the Oxygen Positions. Acta Chem. Scand. A 1980, 34 (1), 93-98.

(16) Miersch, L.; Rüffer, T.; Lang, H.; Schulze, S.; Hietschold, M.; Zahn, D.; Mehring, M. A Novel WaterSoluble Hexanuclear Bismuth Oxido Cluster - Synthesis, Structure and Complexation with Polyacrylate. Eur. J. Inorg. Chem. 2010, 2010 (30), 4763-4769.

(17) Peiris, R. Design and Development of Novel bismuth(III) Complexes as Antibiotics against Helicobacter Pylori and Anti-Leishmanial Drugs. thesis, Monash University. Faculty of Science. Chemistry, 2013.

(18) Andrews, P. C.; Deacon, G. B.; Junk, P. C.; Kumar, I.; MacLellan, J. G. Synthesis, Ethanolysis, and Hydrolysis of Bismuth(III) Ortho-Nitrobenzoate Complexes En Route to a Pearl Necklace-like Polymer of $\mathrm{Bi}_{10}$ OxoClusters. Organometallics 2009, 28 (14), 3999-4008.

(19) Wang, J.; Neaton, J. B.; Zheng, H.; Nagarajan, V.; Ogale, S. B.; Liu, B.; Viehland, D.; Vaithyanathan, V.; Schlom, D. G.; Waghmare, U. V.; et al. Epitaxial $\mathrm{BiFeO}_{3}$ Multiferroic Thin Film Heterostructures. Science 2003, 299 (5613), 1719-1722.

(20) Wang, S. W.; Wang, H.; Wu, X.; Shang, S.; Wang, M.; $\mathrm{Li}, \mathrm{Z}$.; Lu, W. Rapid Thermal Processing of $\mathrm{Bi}_{2} \mathrm{Ti}_{2} \mathrm{O}_{7}$ Thin Films Grown by Chemical Solution Decomposition. J. Cryst. Growth 2001, 224 (3-4), 323-326.

(21) Lu, H.; Wang, S.; Zhao, L.; Dong, B.; Xu, Z.; Li, J. Surfactant-Assisted Hydrothermal Synthesis of $\mathrm{Bi}_{2} \mathrm{O}_{3}$ Nano/microstructures with Tunable Size. RSC Adv. 2012, 2 (8), 3374-3378.

(22) Wosylus, A.; Hoffmann, S.; Schmidt, M.; Ruck, M. InSitu Study of the Solid-Gas Reaction of $\mathrm{BiCl}_{3}$ to $\mathrm{BiOCl}$ via the Intermediate Hydrate $\mathrm{BiCl}_{3} \cdot \mathrm{H}_{2} \mathrm{O}$. Eur. J. Inorg. Chem. 2010, 2010 (10), 1469-1471.

(23) Lazarini, F. Thermal Dehydration of Some Basic Bismuth Nitrates. Thermochim. Acta 1981, 46 (1), 53-55.

(24) Lazarini, $\quad$ F. $\quad$ Tetra- $\mu_{3}-$ Hydroxo- $\mu_{3}-$ Oxohexabismuth(III) Nitrate Tetrahydrate, 
$\left[\mathrm{Bi}_{6} \mathrm{O}_{4}(\mathrm{OH})_{4}\right]\left(\mathrm{NO}_{3}\right)_{6 \cdot 4} \mathrm{H}_{2} \mathrm{O}$. Acta Chem. Scand. A 1979, A33, 219-224.

(25) Lazarini, F. The Crystal Structure of a Bismuth Basic Nitrate, $\left[\mathrm{Bi}_{6} \mathrm{O}_{5}(\mathrm{OH})_{3}\right]\left(\mathrm{NO}_{3}\right)_{5} 3 \mathrm{H}_{2} \mathrm{O}$. Acta Crystallogr. B 1978, 34 (11), 3169-3173.

(26) Brcic, B.; Kolar, D.; Lazarini, F.; Malesic, M. Oxidation of Bismuth with Atmospheric Oxygen in the Presence of Diluted Nitric Acid. Monatsh Chem 1973, 104, 365375 .

(27) Sundvall, B. Crystal Structure of Tetraoxotetrahydroxohexabismuth (III) Perchlorate Heptahydrate, $\mathrm{Bi}_{6} \mathrm{O}_{4}(\mathrm{HO})_{4}\left(\mathrm{ClO}_{4}\right)_{6}{ }_{7} \mathrm{H}_{2} \mathrm{O}$ : An X-Ray and Neutron Diffraction Study. Inorg. Chem. 1983, 22 (13), 1906-1912.

(28) Sundvall, B. Crystal and Molecular Structure of tetraoxotetrahydroxohexabismuth(III) Nitrate Monohydrate, $\mathrm{Bi}_{6} \mathrm{O}_{4}(\mathrm{HO})_{4}\left(\mathrm{NO}_{3}\right)_{6} \mathrm{H}_{2} \mathrm{O}$. Acta Chem Scand Ser A 1979, A33, 219-224.

(29) Sundvall, B.; Kjekshus, A.; Oftedal, T. A.; Andresen, A. F. On the Crystal Structure of Dodecahydroxohexabismuth(III) Perchlorate. Acta Chem. Scand. 1974, 28a, 1036-1037.

(30) Schlesinger, M.; Pathak, A.; Richter, S.; Sattler, D.; Seifert, A.; Rüffer, T.; Andrews, P. C.; Schalley, C. A.; Lang, H.; Mehring, M. Salicylate-Functionalized Bismuth Oxido Clusters: Hydrolysis Processes and Microbiological Activity. Eur. J. Inorg. Chem. 2014, 2014 (25), 4218-4227.

(31) Mansfeld, D.; Miersch, L.; Rüffer, T.; Schaarschmidt, D.; Lang, H.; Böhle, T.; Troff, R. W.; Schalley, C. A.; Müller, J.; Mehring, M. From $\left\{\mathrm{Bi}_{22} \mathrm{O}_{26}\right\}$ to Chiral Ligand-Protected $\left\{\mathrm{Bi}_{38} \mathrm{O}_{45}\right\}$-Based Bismuth Oxido Clusters. Chem. - Eur. J. 2011, 17 (52), 14805-14810.

(32) Boyd, T. D.; Kumar, I.; Wagner, E. E.; Whitmire, K. H. Synthesis and Structural Studies of the Simplest bismuth(III) Oxo-Salicylate Complex: $\left[\mathrm{Bi}_{4}\left(\mu_{3}-\mathrm{O}\right)_{2}(\mathrm{HO}-2-\right.$ $\left.\left.\mathrm{C}_{6} \mathrm{H}_{4} \mathrm{CO}_{2}\right)_{8}\right] \cdot 2$ Solv $\left(\right.$ Solv $=\mathrm{MeCN}$ or $\mathrm{MeNO}_{2}$ ). Chem. Commun. 2014, 50 (27), 3556-3559.

(33) Zhang, H.; Dikarev, E. V. Isolation and Structural Characterization of Bismuth Oxo-Diketonate, $\mathrm{Bi}_{3} 8 \mathrm{O} 45$ (hfac) 24, 2006.

(34) Thurston, J. H.; Swenson, D. C.; Messerle, L. Solvolytic Routes to New Nonabismuth Hydroxy- and AlkoxyOxo Complexes: Synthesis, Characterization and Solid-State Structures of Novel Nonabismuth Polyoxo Cations $\mathrm{Bi}_{9}\left(\mu_{3}-\mathrm{O}\right)_{8}\left(\mu_{3}-\mathrm{OR}\right)_{6}{ }^{5+}(\mathrm{R}=\mathrm{H}$, Et $)$. Chem. Commun. 2005, No. 33, 4228.

(35) Thurston, J. H.; Dougherty, M. J.; Swenson, D. C.; Messerle, L. $\left[\mathrm{Bi}_{5}(\mathrm{dpd})_{6} \subset \mathrm{CH}_{3} \mathrm{CN}\right]\left(\mathrm{ClO}_{4}\right)_{3} \cdot 3 \mathrm{CH}_{3} \mathrm{CN}$ : A Supramolecular, Tetrahedral Pentabismuth Cluster Derived from a Nonabismuth Oxo/hydroxide. Dalton Trans. 2008, No. 38, 5146-5148.

(36) Jones, C. M.; Burkart, M. D.; Whitmire, K. H. Novel Aryloxybismuthoxide Clusters: X-Ray Crystal Structures of $\mathrm{Bi}_{6}\left(\mu_{3}-\mathrm{O}\right)_{7}\left(\mu_{3}-\mathrm{OC}_{6} \mathrm{~F}_{5}\right)\left\{\mathrm{Bi}\left(\mathrm{OC}_{6} \mathrm{~F}_{5}\right)_{4}\right\}_{3}(\text { thf })_{2}$ and $\mathrm{Bi}_{6}\left(\mu_{3}-\mathrm{O}\right)_{7}\left(\mu_{3}-\mathrm{OC}_{6} \mathrm{~F}_{5}\right)\left\{\mathrm{Bi}\left(\mathrm{OC}_{6} \mathrm{~F}_{5}\right)_{4}\right\}_{3}{ }_{2} \mathrm{C}_{7} \mathrm{H}_{8}($ thf $=$ Tetrahydrofuran). J. Chem. Soc. Chem. Commun. 1992, No. 22, 1638-1639.

(37) Andrews, P. C.; Junk, P. C.; Nuzhnaya, I.; Spiccia, L. Fluorinated Bismuth Alkoxides: From Monomers to Polymers and Oxo-Clusters. Dalton Trans. 2008, No. 19, 2557-2568.

(38) Schlesinger, M.; Weber, M.; Rüffer, T.; Lang, H.; Mehring, M. Nanoscaled Bismuth Oxido Clusters: Probing Factors of Structure Formation and Photocatalytic Activity. Eur. J. Inorg. Chem. 2014, 2014 (2), 302-309.
(39) Schlesinger, M.; Weber, M.; Schulze, S.; Hietschold, M.; Mehring, M. Metastable $\beta-\mathrm{Bi}_{2} \mathrm{O}_{3}$ Nanoparticles with Potential for Photocatalytic Water Purification Using Visible Light Irradiation. ChemistryOpen 2013, 2 (4), 146-155.

(40) Schlesinger, M.; Schulze, S.; Hietschold, M.; Mehring, M. Metastable $\beta-\mathrm{Bi}_{2} \mathrm{O}_{3}$ Nanoparticles with High Photocatalytic Activity from Polynuclear Bismuth Oxido Clusters. Dalton Trans. 2012, 42 (4), 1047-1056.

(41) Schlesinger, M.; Miersch, L.; Rüffer, T.; Lang, H.; Mehring, M. Two Novel Nanoscaled Bismuth Oxido Clusters,

$\left[\mathrm{Bi}_{38} \mathrm{O}_{45}(\mathrm{OMc})_{22}\left(\mathrm{C}_{8} \mathrm{H}_{7} \mathrm{SO}_{3}\right)_{2}(\mathrm{DMSO})_{6}\left(\mathrm{H}_{2} \mathrm{O}\right)_{1.5}\right]^{2} \cdot{ }_{5} \mathrm{H}_{2} \mathrm{O}$ and

$\left[\mathrm{Bi}_{38} \mathrm{O}_{45}(\mathrm{HSal})_{22}(\mathrm{OMc})_{2}(\mathrm{DMSO})_{15}\left(\mathrm{H}_{2} \mathrm{O}\right)\right]^{\circ} \mathrm{DMSO}_{2} \mathrm{H}_{2} \mathrm{O}$. Main Group Met. Chem. 2013, 36 (1-2), 11-19.

(42) Sattler, D.; Schlesinger, M.; Mehring, M.; Schalley, C. A. Mass Spectrometry and Gas-Phase Chemistry of Bismuth-Oxido Clusters. ChemPlusChem 2013, 78 (9), 1005-1014.

(43) Miersch, L.; Schlesinger, M.; Troff, R. W.; Schalley, C. A.; Rüffer, T.; Lang, H.; Zahn, D.; Mehring, M. Hydrolysis of a Basic Bismuth Nitrate-Formation and Stability of Novel Bismuth Oxido Clusters. Chem. - Eur. J. 2011, 17 (25), 6985-6990.

(44) Miersch, L.; Rüffer, T.; Mehring, M. Organic-inorganic Hybrid Materials Starting from the Novel Nanoscaled Bismuth Oxido Methacrylate Cluster $\left[\mathrm{Bi}_{38} \mathrm{O}_{45}(\mathrm{OMc})_{24}(\mathrm{DMSO})_{9}\right] \cdot 2 \mathrm{DMSO} \cdot 7 \mathrm{H}_{2} \mathrm{O}$. Chem. Commun. 2011, 47 (22), 6353-6355.

(45) Chandrasekhar, V.; Metre, R. K.; Sahoo, D. Bi ${ }_{38}$ Oxocarboxylate Cages Are Keplerates - Synthesis and Structural Characterization of Two $\mathrm{Bi}_{38}$ Oxocarboxylate Cages. Eur. J. Inorg. Chem. 2014, 2014 (1), 164-171.

(46) Andrews, P. C.; Busse, M.; Junk, P. C.; Forsyth, C. M.; Peiris, R. Sulfonato-Encapsulated bismuth(III) OxidoClusters from $\mathrm{Bi}_{2} \mathrm{O}_{3}$ in Water under Mild Conditions. Chem. Commun. 2012, 48 (61), 7583-7585.

(47) André, V.; Hardeman, A.; Halasz, I.; Stein, R. S.; Jackson, G. J.; Reid, D. G.; Duer, M. J.; Curfs, C.; Duarte, M. T.; Friščić, T. Mechanosynthesis of the Metallodrug Bismuth Subsalicylate from $\mathrm{Bi}_{2} \mathrm{O}_{3}$ and Structure of Bismuth Salicylate without Auxiliary Organic Ligands. Angew. Chem. Int. Ed. 2011, 50 (34), 7858-7861.

(48) Miersch, L.; Rüffer, T.; Schaarschmidt, D.; Lang, H.; Troff, R. W.; Schalley, C. A.; Mehring, M. Synthesis and Characterization of Polynuclear Oxidobismuth Sulfonates. Eur. J. Inorg. Chem. 2013, 2013 (9), 14271433.

(49) Srinivas, K.; Sathyanarayana, A.; Babu, C. N.; Prabusankar, G. Bismuth(III)dichalcogenones as Highly Active Catalysts in Multiple C-C Bond Formation Reactions. Dalton Trans. 2016, 45 (12), 5196-5206.

(50) Kugel, B. Chemie und Koordinationschemie von Trifluoracetaten des Bismuts und des Antimons http://docserv.uni-

duesseldorf.de/servlets/DocumentServlet?id=2890 (accessed Mar 7, 2016).

(51) Kumar, I.; Bhattacharya, P.; Whitmire, K. H. Structural Diversity in Phenyl bismuth(III) Bis(carboxylate) Complexes. J. Organomet. Chem. 2015, 794, 153-167.

(52) Kumar, I.; Andrews, P.; Whitmire, K. H. The Unexpected Isolation of Bismuth Tris(carboxylate) Hydrates: Syntheses and Structures of $\left[\mathrm{Bi}(\mathrm{Hsal})_{3}\left(\mathrm{H}_{2} \mathrm{O}\right)\right]$ and $\left[\mathrm{Bi}(\text { Hanth })_{3}\left(\mathrm{H}_{2} \mathrm{O}\right)\right] \quad\left(\mathrm{H}_{2} \mathrm{sal}=2-\mathrm{OH}-\mathrm{C}_{6} \mathrm{H}_{4} \mathrm{CO}_{2} \mathrm{H}\right.$, Hanth $\left.=2-\mathrm{NH}_{2}-\mathrm{C}_{6} \mathrm{H}_{4} \mathrm{CO}_{2} \mathrm{H}\right)$. Eur. J. Inorg. Chem. 2015, 2015 (4), 605-608. 
(53) Kumar, I.; Bhattacharya, P.; Whitmire, K. H. Facile One-Pot Synthesis of Triphenylbismuth(V) Bis(carboxylate) Complexes. Organometallics 2014, 33 (11), 2906-2909.

(54) Stavila, V.; Fettinger, J. C.; Whitmire, K. H. Synthesis and Characterization of New Phenylbis(salicylato)bismuth(III) Complexes. Organometallics 2007, 26 (14), 3321-3328.

(55) Thurston, J. H.; Marlier, E. M.; Whitmire, K. H. Towards a Molecular Model for bismuth(III) Subsalicylate. Synthesis and Solid-State Structure of $\left[\mathrm{Bi}(\mathrm{Hsal})_{3}(\right.$ bipy $)\left(\mathrm{C}_{7} \mathrm{H}_{8}\right]_{2}$ and $\quad[\mathrm{Bi}(\mathrm{Hsal})(\mathrm{sal})(1,10-$ phenanthroline $)\left(\mathrm{C}_{7} \mathrm{H}_{8}\right]_{2}$. Chem. Commun. 2oo2, No. 23, 2834-2835.

(56) Thurston, J. H.; Trahan, D.; Ould-Ely, T.; Whitmire, K. H. Toward a General Strategy for the Synthesis of Heterobimetallic Coordination Complexes for Use as Precursors to Metal Oxide Materials: Synthesis, Characterization, and Thermal Decomposition of $\mathrm{Bi}_{2}(\mathrm{Hsal})_{6} \cdot \mathrm{M}(\mathrm{Acac})_{3}(\mathrm{M}=\mathrm{Al}, \mathrm{Co}, \mathrm{V}, \mathrm{Fe}, \mathrm{Cr})$. Inorg. Chem. 2004, 43 (10), 3299-3305.

(57) Jones, C. M.; Burkart, M. D.; Whitmire, K. H. Dimeric Alkoxido Bismuth Complexes with Planar $\left[\mathrm{Bi}_{2}(\mu-\mathrm{OR})_{2}\right]$ Units. Synthesis and Structure of $\left[\left\{\mathrm{Bi}\left[\mathrm{OCH}\left(\mathrm{CF}_{3}\right)_{2}\right]_{3}(\mathrm{THF})\right\}_{2}\right] \quad$ and $\left[\mathrm{Bi}\left(\mathrm{OC}_{6} \mathrm{~F}_{5}\right)_{3}\left(\mathrm{C}_{7} \mathrm{H}_{8}\right)\right]_{2}{ }_{2} \mathrm{C}_{7} \mathrm{H}_{8}$. Angew. Chem. Int. Ed. 1992, 104, 446-467.

(58) Whitmire, K. H.; Jones, C. M.; Burkart, M. D.; Chris Hutchison, J.; McKnight, A. L. Aggregation and Hydrolysis Reactions of Bismuth Alkoxides. In Symposium N - Better Ceramics Through Chemistry V; MRS Online Proceedings Library Archive; 1992; Vol. 271, p 149 (6 pages).

(59) Jolas, J. L.; Hoppe, S.; Whitmire, K. H. Oligomerization and Oxide Formation in Bismuth Aryloxides: Synthesis, Characterization, and Structures of [Na$\left.\mathrm{Bi}\left(\mathrm{OC}_{6} \mathrm{~F}_{5}\right)_{4}(\mathrm{THF})\right]_{\infty}$ and $\mathrm{Na}_{4} \mathrm{Bi}_{2}\left(\mu_{6}-\mathrm{O}\right)\left(\mathrm{OC}_{6} \mathrm{~F}_{5}\right)_{8}(\mathrm{THF})_{4}$. Inorg. Chem. 1997, 36 (15), 3335-3340.

(6o) Asato, E.; Katsura, K.; Mikuriya, M.; Fujii, T.; Reedijk, J. Isolation of a Unique Hexanuclear $\left[\mathrm{Bi}_{6} \mathrm{O}_{4} \mathrm{OH}(\mathrm{cit})_{3}\left(\mathrm{H}_{2} \mathrm{O}\right)_{3}\right]^{3-}$ Cluster from the BismuthContaining Ulcer Healing Agent "Colloidal Bismuth Subcitrate (CBS).” Chem. Lett. 1992, 21 (10), 1967-1970.

(61) Asato, E.; Katsura, K.; Mikuriya, M.; Turpeinen, U.; Mutikainen, I.; Reedijk, J. Synthesis, Structure, and Spectroscopic Properties of Bismuth Citrate Compounds and the Bismuth-Containing Ulcer-Healing Agent Colloidal Bismuth Subcitrate (CBS). 4. Crystal Structure and Solution Behavior of a Unique Dodecanuclear Cluster $\left(\mathrm{NH}_{4}\right)_{12}\left[\mathrm{Bi}_{12} \mathrm{O}_{8}(\mathrm{cit})_{8}\right]\left(\mathrm{H}_{2} \mathrm{O}\right)_{10}$. Inorg. Chem. 1995, 34 (9), 2447-2454.

(62) Miersch, L.; Rüffer, T.; Schlesinger, M.; Lang, H.; Mehring, M. Hydrolysis Studies on Bismuth Nitrate: Synthesis and Crystallization of Four Novel Polynuclear Basic Bismuth Nitrates. Inorg. Chem. 2012, 51 (17), 9376-9384.

(63) Cherkasova, T. G.; Golubenko, N. A.; Tatarinova, E. S. Russ. J. Inorg. Chem. 2005, 50, 1482.

(64) Kawamura, M.; Cui, D.-M.; Shimada, S. Friedel-Crafts Acylation Reaction Using Carboxylic Acids as Acylating Agents. Tetrahedron 2006, 62 (39), 9201-9209.

(65) Rogow, D.; Fei, H.; Brennan, D.; Ikehata, M.; Zavalij, P.; Oliver, A.; Oliver, S. Hydrothermal Synthesis of Two Cationic Bismuthate Clusters: An Alkylenedisulfonate Bridged Hexamer, $\left[\mathrm{Bi}_{6} \mathrm{O}_{4}(\mathrm{OH})_{4}\left(\mathrm{H}_{2} \mathrm{O}\right)_{2}\right]\left[\left(\mathrm{CH}_{2}\right)_{2}\left(\mathrm{SO}_{3}\right)_{2}\right]_{3}$ and a Rare Nonamer Templated by Triflate,
$\left[\mathrm{Bi}_{9} \mathrm{O}_{8}(\mathrm{OH})_{6}\right]\left[\mathrm{CF}_{3} \mathrm{SO}_{3}\right]_{5}$ Inorg. Chem. 2010, 49 (12), 5619-5624.

(66) Veronese, A. C.; Morelli, C. F.; Callegari, R.; Basato, M. Metal-Catalysed Carbon-Carbon Bond Formation in the Reaction of Malononitrile with $\beta$-Dicarbonyls. J. Mol. Cat. A 1997, 124 (2), 99-107.

(67) Basato, M.; Vettori, U.; Veronese, A. C.; Grassi, A.; Valle, G. Synthesis of Beta-Imino Carbonyl Enolato Complexes by Reaction of Nickel(II), Palladium(II), and Copper(II) Acetates with the Enaminodiones $\left.(\mathrm{MeOCO})(\mathrm{RCO}) \mathrm{CC}\left(\mathrm{R}^{\prime}\right) \mathrm{NH}{ }_{2}\right)\left(\mathrm{R}=\mathrm{Me}, \mathrm{OMe} ; \mathrm{R}^{\prime}=\mathrm{Et}\right.$, EtOCO). Inorg. Chem. 1998, 37 (26), 6737-6745.

(68) Albert Cotton, F.; Daniels, L. M.; Jordan IV, G. T.; Murillo, C. A. The Exceptional Structural Versatility of 2,2' -Dipyridylamine (Hdpa) and Its Ions [dpa]- and [ $\left.\mathrm{H}_{2} \mathrm{dpa}\right]+$. Polyhedron 1998, 17 (4), 589-597.

(69) Hijazi, A. K.; Al Hmaideen, A.; Syukri, S.; Radhakrishnan, N.; Herdtweck, E.; Voit, B.; Kühn, F. E. Synthesis and Characterization of Acetonitrile-Ligated Transition-Metal Complexes with Tetrakis(pentafluorophenyl)borate as Counteranions. Eur. J. Inorg. Chem. 2008, 2008 (18), 2892-2898.

(70) Veith, M.; Gödicke, B.; Huch, V. Darstellung Und Strukturen von Chlorostannaten(II). II. Neue Chlorostannate(II) von Zweiwertigen Kationen. Z. Für Anorg. Allg. Chem. 1989, 579 (1), 99-110.

(71) Mondal, A.; Durdevic, S.; Chamoreau, L.-M.; Journaux, Y.; Julve, M.; Lisnard, L.; Lescouëzec, R. A Cyanide and Hydroxo-Bridged Nanocage: A New Generation of Coordination Clusters. Chem. Commun. Camb. Engl. 2013, 49 (12), 1181-1183.

(72) Gao, Q.; Wang, X.; Tapp, J.; Moeller, A.; Jacobson, A. J. Antimony Tartrate Transition-Metal-Oxo Chiral Clusters. Inorg. Chem. 2013, 52 (11), 6610-6616.

(73) Antonova, E.; Näther, C.; Kögerler, P.; Bensch, W. Expansion of Antimonato Polyoxovanadates with Transition Metal Complexes: $\left(\mathrm{Co}\left(\mathrm{N}_{3} \mathrm{C}_{5} \mathrm{H}_{15}\right)_{2}\right)_{2}\left[\left\{\mathrm{Co}\left(\mathrm{N}_{3} \mathrm{C}_{5} \mathrm{H}_{15}\right)_{2}\right\} \mathrm{V}_{15} \mathrm{Sb}_{6} \mathrm{O}_{42}\left(\mathrm{H}_{2} \mathrm{O}\right)\right]{ }_{5} \mathrm{H}_{2} \mathrm{O}$ and

$\left(\mathrm{Ni}\left(\mathrm{N}_{3} \mathrm{C}_{5} \mathrm{H}_{15}\right)_{2}\right)_{2}\left[\left\{\mathrm{Ni}\left(\mathrm{N}_{3} \mathrm{C}_{5} \mathrm{H}_{15}\right)_{2}\right\} \mathrm{V}_{15} \mathrm{Sb}_{6} \mathrm{O}_{42}\left(\mathrm{H}_{2} \mathrm{O}\right)\right] \cdot 8 \mathrm{H}_{2} \mathrm{O}$. Inorg. Chem. 2012, 51 (4), 2311-2317.

(74) Hathaway, B. J.; Holah, D. G.; Underhill, A. E. 468. The Preparation and Properties of Some Bivalent Transition-Metal Tetrafluoroborate-methyl Cyanide Complexes. J. Chem. Soc. Resumed 1962, No. o, 2444-2448.

(75) Hathaway, B. J.; Holah, D. G.; Postlethwaite, J. D. 630. The Preparation and Properties of Some tetrakis(methylcyanide)copper(I) Complexes. J. Chem. Soc. Resumed 1961, No. o, 3215-3218.

(76) Fielden, J.; Long, D.-L.; Cronin, L.; Kögerler, P. Synthesis of $\mathrm{Cu}(\mathrm{I})$ Octamolybdates Using Tetrakisacetonitrilecopper(I) Hexafluorophosphate. Polyhedron 2009, 28 (13), 2803-2807.

(77) Fielden, J.; Quasdorf, K.; Cronin, L.; Kögerler, P. A Fluorophosphate-Based Inverse Keggin Structure. Dalton Trans. 2003 2012, 41 (33), 9876-9878.

(78) Moreno Pineda, E.; Heesing, C.; Tuna, F.; Zheng, Y.-Z.; McInnes, E. J. L.; Schnack, J.; Winpenny, R. E. P. Copper Lanthanide Phosphonate Cages: Highly Symmetric $\left\{\mathrm{Cu}_{3} \mathrm{Ln}_{9} \mathrm{P}_{6}\right\}$ and $\left\{\mathrm{Cu}_{6} \mathrm{Ln}_{6} \mathrm{P}_{6}\right\}$ Clusters with $\mathrm{C}_{3 \mathrm{v}}$ and $\mathrm{D}_{3} \mathrm{~h}$ Symmetry. Inorg. Chem. 2015, 54 (13), 6331-6337.

(79) Llewellyn, D. B.; Adamson, D.; Arndtsen, B. A. A Novel Example of Chiral Counteranion Induced Enantioselective Metal Catalysis: The Importance of Ion-Pairing in Copper-Catalyzed Olefin Aziridination and Cyclopropanation. Org. Lett. 20oo, 2 (26), 4165-4168. 
(80) Becker, S.; Behrens, U.; Schindler, S. Investigations Concerning $\left[\mathrm{Cu}_{4} \mathrm{OX}_{6} \mathrm{~L}_{4}\right]$ Cluster Formation of Copper(II) Chloride with Amine Ligands Related to Benzylamine. Eur. J. Inorg. Chem. 2015, 2015 (14), 24372447.

(81) Davies, J. A. Synthetic Coordination Chemistry: Principles and Practice; World Scientific, 1996.

(82) Sharutin, V. V.; Egorova, I. V.; Sharutina, O. K.; Ivanenko, T. K.; Adonin, N. Y.; Starichenko, V. F.; Pushilin, M. A.; Gerasimenko, A. V. Tetranuclear Bismuth Complex $\quad \mathrm{Bi}_{4}(\mathrm{O})_{2}\left(\mathrm{O}_{2} \mathrm{CC}_{6} \mathrm{H}_{2} \mathrm{~F}_{3}-3,4,5,\right)_{8} 2 \eta^{6}$ $\mathrm{C}_{6} \mathrm{H}_{5} \mathrm{Me}$ : Synthesis and Structure. Russ. J. Coord. Chem. 2003, 29 (12), 838-844.

(83) Kou, X.; Wang, X.; Mendoza-Espinosa, D.; Zakharov, L. N.; Rheingold, A. L.; Watson, W. H.; Brien, K. A.; Jayarathna, L. K.; Hanna, T. A. Bismuth Aryloxides. Inorg. Chem. 2009, 48 (23), 11002-11016.

(84) Liu, L.; Zakharov, L. N.; Rheingold, A. L.; Hanna, T. A. Synthesis and X-Ray Crystal Structures of the First Antimony and Bismuth Calixarene Complexes. Chem. Commun. 2004, No. 13, 1472-1473.
(85) Mendoza-Espinosa, D.; Hanna, T. A. Synthesis, X-Ray Structures and Reactivity of calix[5]arene bismuth(III) and antimony(III) Complexes. Dalton Trans. 2009, No. 26, 5211-5225.

(86) Uchiyama, Y.; Kano, N.; Kawashima, T. Synthesis and Structure of a Novel Ladder-Type Organobismuth Compound with Bismuth-Oxygen Interactions. Organometallics 2001, 20 (12), 2440-2442.

(87) Matano, Y.; Nomura, H.; Haisanga, T.; Nakano, H.; Shiro, M.; Imahori, H. Diverse Structures and Remarkable Oxidizing Ability of Triarylbismuthane Oxides. Comparative Study on the Structure and Reactivity of a Series of Triarylpnictogen Oxides. Organometallics 2004, 23 (23), 5471-5480.

(88) Hatanpää, T.; Vehkamäki, M.; Ritala, M.; Leskelä, M. Study of Bismuth Alkoxides as Possible Precursors for ALD. Dalton Trans. 2010, 39 (13), 3219-3226. 


\section{For Table of Contents Only}

Anionic bismuth oxido carboxylates are produced readily from $\mathrm{BiPh}_{3}$ and trifluoroacetic acid in the presence of metal complexes that can serve as the source of $\mathrm{ML}_{\mathrm{n}}{ }^{\mathrm{x}}$ countercations. These cations stabilize the addition trifluoroacetate anions to neutral bismuth oxido carboxylate cores. In this fashion the new anions have been prepared: $\left[\mathrm{Bi}_{6}\left(\mu_{3}-\mathrm{O}\right)_{4}\left(\mu_{3}-\mathrm{OH}\right)_{4}\left(\mathrm{CF}_{3} \mathrm{CO}_{2}\right)_{12}\right]^{6-},\left\{\left[\mathrm{Bi}_{4}\left(\mu_{3}-\mathrm{O}\right)_{2}\left(\mathrm{CF}_{3} \mathrm{CO}_{2}\right)_{10}\right]^{2-}\right\}_{\mathrm{n}}$. The new cation $\left[\mathrm{Co}\left\{(\mathrm{MeC})_{3} \mathrm{CH}(\mathrm{NH}) \mathrm{O}_{2}\right\}_{2}\right]^{3+}$ was created by coupling $\mathrm{Co}(\mathrm{acac})_{3}$ and $\mathrm{MeCN}$ and a previously unreported hexanitrato complex of bismuth, $\left[\mathrm{Co}\left\{(\mathrm{MeC})_{3} \mathrm{CH}(\mathrm{NH}) \mathrm{O}_{2}\right\}_{2}\right]\left[\mathrm{Bi}\left(\mathrm{NO}_{3}\right)_{6}\right]$, was characterized.

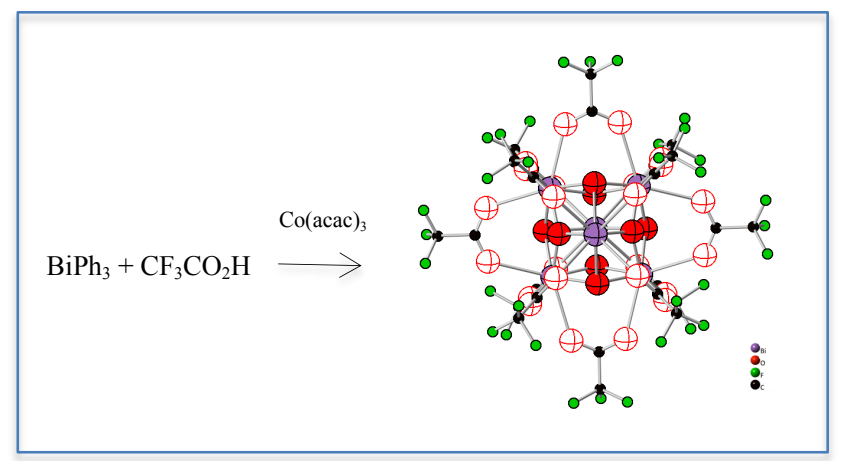

